\title{
Downscaling CMIP6 Global Solutions to Regional Ocean Carbon Model: Connecting the Mississippi, Gulf of Mexico, and Global Ocean
}

\author{
Le Zhang ${ }^{1}$ and Z. George Xue ${ }^{1,2,3}$
}

${ }^{1}$ Department of Oceanography and Coastal Sciences, Louisiana State University, Baton Rouge, LA 70803

$5 \quad{ }^{2}$ Center for Computation and Technology, Louisiana State University, Baton Rouge, LA 70803

${ }^{3}$ Coastal Studies Institute, Louisiana State University, Baton Rouge, LA 70803

Correspondence to: Z. George Xue (zxue@1su.edu)

\begin{abstract}
Coupled physical-biogeochemical models can significantly reduce uncertainties in estimating the spatial and temporal patterns of the ocean carbon system. Challenges of applying a coupled physical-biogeochemical model in the regional ocean include the reasonable prescription of carbon model boundary conditions, lack of in situ observations, and the oversimplification of certain biogeochemical processes. In this study, we applied a coupled physical-biogeochemical model (Regional Ocean Modelling System, ROMS) to the Gulf of Mexico (GoM) and achieved an unprecedented 20-year highresolution $\left(5 \mathrm{~km}, 1 / 22^{\circ}\right)$ hindcast covering the period of 2000-2019. The model's biogeochemical cycle is driven by the Coupled Model Intercomparison Project 6-Community Earth System Model 2 products (CMIP6-CESM2) and incorporates the

15 dynamics of dissolved organic carbon (DOC) pools as well as the formation and dissolution of carbonate minerals. Model outputs include generally interested carbon system variables, such as $\mathrm{pCO}_{2}, \mathrm{pH}$, aragonite saturation state $\left(\Omega_{\mathrm{Arag}}\right)$, calcite saturation state ( $\Omega_{\text {Calc }}$ ), $\mathrm{CO}_{2}$ air-sea flux, carbon burial rate, etc. The model's robustness is evaluated via extensive model-data comparison against buoy, remote sensing-based Machine Learning (ML) predictions, and ship-based measurements. Model results reveal that the GoM water has been experiencing an $\sim 0.0016 \mathrm{yr}^{-1}$ decrease in surface $p H$ over the past two decades, accompanied by a $\sim 1.66 \mu \mathrm{atm} \mathrm{yr}^{-1}$ increase in sea surface $\mathrm{pCO}_{2}$. The air-sea $\mathrm{CO}_{2}$ exchange estimation confirms that the riverdominated northern GoM is a substantial carbon sink. The open water of GoM, affected mainly by the thermal effect, is a carbon source during summer and a carbon sink for the rest of the year. Sensitivity experiments are conducted to evaluate the impacts from river inputs and the global ocean via model boundaries. Our results show that the coastal ocean carbon cycle is dominated by enormous carbon inputs from the Mississippi River and nutrient-stimulated biological activities, and the carbon system condition of the open ocean is primarily driven by inputs from the Caribbean Sea via Yucatan Channel.
\end{abstract}

\section{Introduction}

Carbon dioxide $\left(\mathrm{CO}_{2}\right)$ concentration in the atmosphere has increased approximately 150\% from 1750 to 2019 (Le Quéré et al., 2018), the storage and transport of carbon in Earth's ecosystem under the context of climate change has been receiving incremental attention over the past decades (Anav et al., 2013; Lindsay et al., 2014; Jones et al., 2016). The direction and magnitude of ocean-atmosphere $\mathrm{CO}_{2}$ fluxes are subject to change with increasing atmospheric $\mathrm{CO}_{2}$ concentrations (Smith \& 
https://doi.org/10.5194/bg-2021-339

Preprint. Discussion started: 17 December 2021

(c) Author(s) 2021. CC BY 4.0 License.

\section{(c) (i)}

Hollibaugh 1993, Wollast \& Mackenzie 1989), incremental ocean dissolved inorganic carbon (DIC) level (Torres et al., 2011), modification of the coastal alkalinity generation process (Renforth \& Henderson, 2017), changes in organic matter (OM) remineralization patterns (Buesseler et al., 2020), river inputs (Yao \& Hu, 2017), etc. As an enormous reservoir, the ocean has intake some $170 \pm 20 \mathrm{PgC}$ (Le Quéré et al., 2018) since the industrial revolution. This alleviates the $\mathrm{CO}_{2}$ accumulation rate in the atmosphere while inducing a consequent increase in ocean carbon level and a decrease in ocean $\mathrm{pH}$ and calcium mineral saturation state $(\Omega$, Doney et al., 2009). Given the stakes it holds in shaping climate feedback in the long term and risk for coastal ecosystems under acidification stress, carbon sink quantities and their trends have been studied and monitored by multiple works (Maher \& Eyre, 2012; Czerny et al. 2013; Najjar et al., 2018; Bushinsky et al. 2019).

40 Nevertheless, uncertainties and mismatches in carbon flux estimates among different works and difficulties in describing the spatial and temporal pattern of $\mathrm{pCO}_{2}$ data collected from ship-based measurements left many vital questions unanswered. Global Earth System Models (ESMs) are essential tools for studying the linkage between the ocean carbon cycle and climate change. Extensive utilization of ESMs in hindcasting and coupled biogeochemistry provide pivotal information for understanding the carbon cycle on a global scale (Anav et al., 2013; Laurent, Fennel, \& Kuhn, 2021; Lindsay et al., 2014;

45 Jones et al., 2016; Todd-Brown et al., 2014). However, their relatively coarse spatial resolution is likely not appropriate to be directly compared with field measurements. It is imperative to apply high-resolution regional ocean models to understand carbon exchange and carbon budget at a regional scale. While high-resolution regional models have been developed to represent the complex patterns of ocean circulation and elemental fluxes on the continental shelves, the regional ocean carbon system is challenging to model and predict due to its high sensitivity to the boundary and initial conditions, uncertainties in the carbon pathway, and complex interactions between the atmosphere, ocean, and land (Hofmann et al., 2011).

The Gulf of Mexico (GoM) is a semi-closed marginal sea. The presence of Mississippi-Atchafalaya River System (MARS) and the obstructions from Florida Strait and Yucatan Channel mitigate the impact from the global ocean into the GoM regarding water acidity and carbon levels. Allochthonous nutrients from river input, upwelling, and boundary shape the general pattern of the carbon cycling in the GoM (Cai et al., 2011; Chen et al., 2000; Delgado et al.,2019; Dzwonkowski et al., 2018; Laurent et al., 2017; Jiang et al., 2019; Sunda \& Cai, 2012; Wang et al., 2016), and need to be properly included in the carbon system modeling in GoM. Fennel et al. (2011) performed a coupled physical-biological modeling of the northern GoM (NGoM) shelf with nitrogen cycle to describe the phytoplankton variability under the influence of the MARS covering the period of 19902004. They found that biomass accumulation in the light-limited plume region near the Mississippi River delta was not

60 primarily controlled bottom-up by nutrient stimulation because of the lack of nutrient limitation in the eutrophic region. Xue et al. (2016) achieved a first GoM carbon budget and concluded that the export of carbon out of the Gulf via Loop Current is largely balanced by river inputs and influx from the air. Their regional carbon model used three sets of initial and open boundary conditions derived from empirical salinity-temperature-DIC-alkalinity relationships. Although this method of carbon system prescription leveraged the convenience of widely available physical variables and was feasible for regions with scarce 
https://doi.org/10.5194/bg-2021-339

Preprint. Discussion started: 17 December 2021

(c) Author(s) 2021. CC BY 4.0 License.

\section{(c) (i)}

65 DIC and alkalinity data, its reliability was questionable as temperature and salinity alone cannot fully describe the spatial and temporal pattern of these carbon variables. Laurent et al. (2017) presented a regional model study of the eutrophication-driven acidification and simulated the recurring development of an extended acidified bottom waters in summer on the NGoM shelf. They proved that the acidified waters were confined to a thin bottom boundary layer where the production of $\mathrm{CO}_{2}$ was dominated by benthic metabolic processes. Despite reduced $\Omega$ values being produced at bottom water due to acidification,

70 these regions remain supersaturated with aragonite. Chen et al. (2019) presented a unified model to estimate surface $p \mathrm{CO}_{2}$ by applying Machine Learning (ML) methods on remote sensing data and cruise $\mathrm{pCO}_{2}$ measurements. Their ML model confirmed that the GoM was a carbon sink. Recently Gomez et al. (2020) performed another GoM carbon model study covering the period of 1981- 2014. Their model initial and boundary conditions were derived from a downscaled Coupled Model Intercomparison Project 5 (CMIP5) Modular Ocean Model (25km resolution, Liu et al., 2015). Their model results showed

75 that GoM was a sink for atmospheric $\mathrm{CO}_{2}$ during winter-spring, and a source during summer-fall, producing a basin-wide mean $\mathrm{CO}_{2}$ uptake of $0.35 \mathrm{~mol} \mathrm{~m}^{-2} \mathrm{yr}^{-1}$. Nevertheless, their model does not include DOC pool or calcification process, which are imperative to describe the dynamic of DIC and alkalinity in the ocean.

Despite the above carbon system regional modeling efforts, we notice that several processes that could contribute significantly

80 to the carbon cycle in the GoM have not been investigated yet. The carbon cycle in the ocean is linked with the nutrient cycle through photosynthetic activities, calcification, and OM remineralization (Anav et al., 2013; Farmer et al., 2021; King et al., 2015). OM remineralization could be the most critical mechanism regulating the ocean carbon system, followed by the $\mathrm{CaCO}_{3}$ cycle (Lauvset et al., 2020), with the remineralization of small detritus accounting for over $40 \%$ of the DIC production on the shelf (Laurent et al., 2017). Autochthonous nutrients from direct remineralization of OM determine the gradient of DIC in the 85 euphotic layer (Boscolo-Galazzo et al., 2021; Boyd et al., 2019). During this process, the fast-sinking of OM, higher OM particulate to dissolved ratio foster larger sedimentation rate and greater DIC removal of the euphotic layers; on the contrary, slower sinking and faster decomposition rate of OM favors nutrient and DIC retention in the euphotic layers (Davis et al., 2019; Mari et al., 2017; Turner, 2015). The remineralization of land-derived $\mathrm{OM}$ and $\mathrm{CaCO}_{3}$ precipitation are significant factors controlling air-sea $\mathrm{CO}_{2}$ flux (Mackenzie et al. 2004). Studies have revealed the formation of marine $\mathrm{CaCO}_{3}$ (Burton

90 and Walter,1987; Inskeep and Bloom, 1985; Zhong and Mucci, 1989; Zuddas and Mucci, 1998) and the dissolution of marine $\mathrm{CaCO}_{3}$ mineral is $\Omega$-dependent as well (Adkins et al. 2021). The $\Omega$ will be depressed with more $\mathrm{CO}_{2}$ dissolves in seawater and can be used as an indicator for the buffering capacity of the ocean carbonate system. Given that $\Omega$ influences the calcification rate of marine organisms and regulates the acidity of bottom waters, it should be considered in the $\mathrm{CaCO}_{3}$ cycle for a comprehensive carbon cycle assessment.

95

In this study, we dynamically downscaled the solution of the latest Coupled Model Intercomparison Project 6 (CMIP6) product to a regional model to inherit the climate perturbation signals (Liao et al., 2020) and the accumulative effect of carbon variables from the global solutions. Our regional model includes critical carbon cycle processes lacking in previous efforts, including 
https://doi.org/10.5194/bg-2021-339

Preprint. Discussion started: 17 December 2021

(c) Author(s) 2021. CC BY 4.0 License.

(c) (i)

the most up-to-date carbonate chemistry thermodynamic parameterization, phosphate cycling, formation \& dissolution of

$\mathrm{CaCO}_{3}$, and the inclusion of the DOC as a semi-labile carbon pool. The objective of this study is 1) to assess the feasibility and robustness of utilizing downscaled global model products to drive a regional coupled physical-biogeochemical model, and 2 ) to examine the temporal trend of key variables of the carbon system $\left(\mathrm{pCO}_{2}, \mathrm{pH}\right.$, air-sea $\mathrm{CO}_{2}$ exchange, and $\Omega$ ) of the surface ocean in the GoM. In addition, to evaluate the impact of MARS and the global ocean on GoM's carbon cycling, two perturbed experiments are designed. The following sections are organized: model setup is given in Sect. 2; in Sect. 3, we validate the model's performance against buoy, remote sensing-based ML solution, and ship-based measurements; the trend of key carbon systems over the past two decades are given in Sect. 4; an assessment of the contribution of riverine inputs and global ocean are discussed in Sect. 5, together with a model uncertainty analysis.

\section{Method}

\subsection{Model setup}

110 Our model is built on the platform of Coupled Ocean-Atmosphere-Wave-Sediment Transport modeling system (COAWST; Warner et al., 2010). COAWST is an open-source community model which includes the Model Coupling Toolkit to allow data exchange among three state-of-the-art numerical models: Regional Ocean Modelling System [ROMS, svn 820, Haidvogel et al., 2008; Shchepetkin and McWilliams, 2005], the Weather Research and Forecasting model [WRF, Skamarock, et al., 2005], and the Simulating Waves Nearshore model [SWAN, Booij et al., 1999]. The carbon model presented in this study is based on

115 a well-validated coupled physical-biogeochemical model by Zang et al. (2019 and 2020), which covers the entire GoM waters (Gulf-COAWST, Fig. 1). The Gulf-COAWST has a horizontal grid resolution of $\sim 5 \mathrm{~km}$ and 36 sigma-coordinate (terrainfollowing) vertical levels. A third-order upstream horizontal advection and fourth-order centred vertical advection are used for momentum and tracer advection. The biogeochemical model is developed based mainly on the pelagic N-based biogeochemical model Pacific Ecosystem Model for Understanding Regional Oceanography (NEMURO, Kishi, et al., 2007;

120 Kishi et al., 2011). In this study, we extend the number of the NEMURO's state variables from seven to seventeen, including nitrate $\left(\mathrm{NO}_{3}\right)$, ammonium $\left(\mathrm{NH}_{4}\right)$, two phytoplankton groups (small phytoplankton, diatom), one explicit phosphorus pool $\mathrm{PO}_{4}$, two pools of silicon (particulate silica, and silicic acid), three zooplankton groups (micro-zooplankton, meso-zooplankton, and predator-zooplankton) and two pools of detritus containing carbon (particulate organic nitrogen [PON], particulate inorganic carbon [CalC], a dissolved organic carbon (DOC) pool, a dissolved organic nitrogen pool (DON), oxygen $\left(\mathrm{O}_{2}\right)$ to regulate the availability of aerobic OM remineralization, dissolved inorganic carbon (DIC) for bookkeeping the sum of dissolved inorganic carbon species in water, and total alkalinity (TA) for bookkeeping the acid neutralization capacity of water. The stoichiometry between carbon and nitrogen in the OM production and remineralization is set to 6.625 following Fennel (2008). 


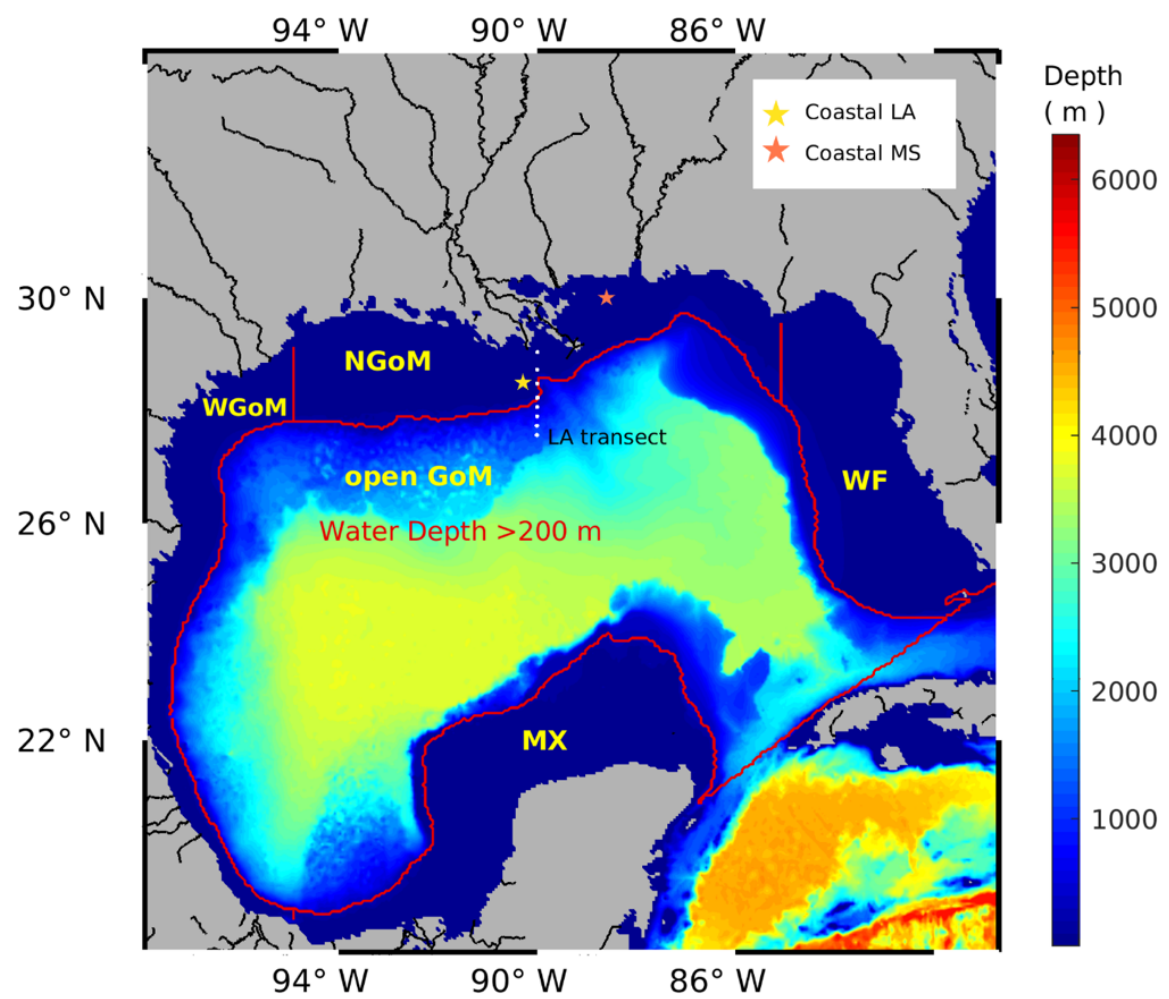

Figure 1: Gulf-COAWST model domain with water depth in color (unit: m). Subregional definitions followed Xue et al. (2016), which are Mexico Shelf (MX), Western Gulf of Mexico Shelf (WGoM), Northern Gulf of Mexico Shelf (NGoM), West Florida Shelf (WF), and Open GoM.

The revised biogeochemical model incorporates key processes regulating the carbon model, including primary production, river DIC, PON and DOC delivery, sediment carbon burial, $\mathrm{CO}_{2}$ air-sea flux, $\mathrm{CaCO}_{3}$ cycling, and $\mathrm{OM}$ remineralization (Fig. 2). Widely used carbon system variables, such as $\mathrm{pCO}_{2}, \mathrm{pH}, \Omega$, etc., are used as carbon system state indicators. The carbon module that takes in DIC, TA, $\mathrm{PO}_{4}, \mathrm{Si}$ (dissolved inorganic silicon), salt, temp, for calculating $p C \mathrm{O}_{2}, p H, \Omega_{\mathrm{Arag}}$, and $\Omega_{\text {Calc, }}$ largely followed the recommended best practices (Dickson, Sabine, \& Christian, 2007; Eyring et al., 2016; Orr et al., 2017; Zeebe and wolf-Gladrow, 2001), with an updated parameter prescription for dissociation constants for carbonic acid $(K 1)$ and bicarbonate ion (K2) (Millero, 2010), and solubility products for aragonite $K_{\mathrm{A}}$ and calcite $K_{\mathrm{C}}$ (Mucci, 1983).

Inorganic carbonate mineral (mainly $\mathrm{CaCO}_{3}$ ) forms during the photosynthetic activities of some phytoplankton species and foster aggregation of detritus and their sinking. The rate of $\mathrm{CaCO}_{3}$ production followed a dynamic ratio regarding primary production of small phytoplankton with low-temperature inhibition and enhancement during bloom conditions (Moore et al.,

145 2004). The production and dissolution of $\mathrm{CaCO}_{3}$ are important processes for ocean acidity regulation, as its production (by 1 unit) nominally takes away a unit of $\left[\mathrm{CO}_{3}{ }^{2-}\right]$ from water, which reduces the alkalinity and DIC by 2 and 1 unit, respectively. This process routinely happens during photosynthetic activities of some phytoplankton species (such as coccolithophores, 
parameterized implicitly as a portion of small phytoplankton in this model) and other marine calcifiers. Carbonate minerals produced in the euphotic zone could be treated as equivalent storage of alkalinity and are usually transported towards the ocean sediment through sinking. Aragonite and calcite are two common mineral phases of $\mathrm{CaCO}_{3}$ secreted by marine organisms and are included in the model. $\Omega_{\text {Calc }}$ and $\Omega_{\text {Arag }}$ are calculated as the equilibrium product of $\mathrm{Ca}^{2+}$ and $\mathrm{CO}_{3}{ }^{2-}$. When $\Omega>1$, calcification is thermodynamically favored, and when $\Omega<1$, dissolution is thermodynamically favored. As defined in Eq. (1), [Ca $\left.{ }^{2+}\right]$ and $\left[\mathrm{CO}_{3}{ }^{2-}\right]$ are the concentrations of calcium and carbonate ions, respectively. $\left[\mathrm{Ca}^{2+}\right]$ is determined through salinity (Millero, 1982; Millero, 1995), and $\left[\mathrm{CO}_{3}{ }^{2-}\right]$ is calculated through the model carbon module. $K_{\mathrm{sp}}$ is the stoichiometric solubility product mainly dependent on pressure, temperature, and salinity. $K_{\mathrm{sp}}$ is defined for aragonite and calcite as $K_{\mathrm{A}}$ and calcite $K_{\mathrm{C}}$, respectively.

$$
\Omega=\frac{\left[\mathrm{Ca}^{2+}\right]\left[\mathrm{CO}_{3}^{2-}\right]}{K_{s p}}
$$

In our model, the sediment pool of sinking particles is a simplified representation of burial and benthic remineralization processes, where the flux of sinking materials out of the bottommost grid point is added to the sediment pool and entered the burial pool (remain inactive) with a dynamic ratio, the active sediment pools undergo enzyme-aided decomposition at rates regulated by temperature and oxygen, and release corresponding influx of ammonium, DIC, and alkalinity at the sediment/water interface. Our model uses a $\mathrm{CO}_{2}$ production ratio of 0.138 between sediment aerobic respiration and denitrification (Fennel et al., 2006) and an alkalinity production ratio of 1.93 between pyrite burial and denitrification (Hu \&

165 Cai, 2011). Upon being sunk to acidified regions, the dissolution of $\mathrm{CaCO}_{3}$, regulated by $\Omega$, can consume dissolved $\mathrm{CO}_{2}$ and neutralize the acid.

The bulk formula for air-sea gas exchange for $\mathrm{CO}_{2}$ is used following Wanninkhof (1992). Air-sea $\mathrm{CO}_{2}$ flux is calculated as Eq (2).

$$
F_{C O 2}=k_{660}\left(\frac{S c}{660}\right)^{-1 / 2} s \Delta p C O_{2}
$$

Where $F_{\mathrm{CO} 2}$ is the air-sea $\mathrm{CO}_{2}$ flux in the unit of $\mathrm{mmol} \mathrm{CO}_{2} \mathrm{~m}^{-2} \mathrm{~d}^{-1} . S c$ is the Schmidt number (nondimensional) (calculated following Wanninkhof, 2014), $s$ is the solubility of $\mathrm{CO}_{2}$ in seawater in $\mathrm{mol} \mathrm{CO}_{2} \mathrm{~m}^{-3} \mu \mathrm{atm}^{-1}$ (calculated following Weiss, 1974), and $\triangle p \mathrm{pO}_{2}$ is the air and sea $p \mathrm{pO}_{2}$ difference in $\mu \mathrm{atm}$. The term $k_{660}$ is the quadratic gas transfer coefficient in $\mathrm{cm} \mathrm{h}^{-1}$ (converted to $\mathrm{m} \mathrm{d}^{-1}$ ). We calculated the air-sea $\mathrm{CO}_{2}$ flux using the relationships of gas exchange with wind speed at $10 \mathrm{~m}$ over the sea surface $\left(\mathrm{U}_{10}\right)$ following Wanninkhof (1992). We used the ocean convention for the $\mathrm{CO}_{2}$ flux, i.e., a positive flux is defined as the ocean being a sink of atmospheric $\mathrm{CO}_{2}$. Air $p \mathrm{CO}_{2}$ level is prescribed using fitted curve from column-averaged dry-air mole fraction of atmospheric carbon dioxide from 2002 to present derived from satellite product (merged dataset from SCIAMACHY/ENVISAT, TANSO-FTS/GOSAT, and OCO-2 [https://cds.climate.copernicus.eu/; Dils et al., 2014]). 


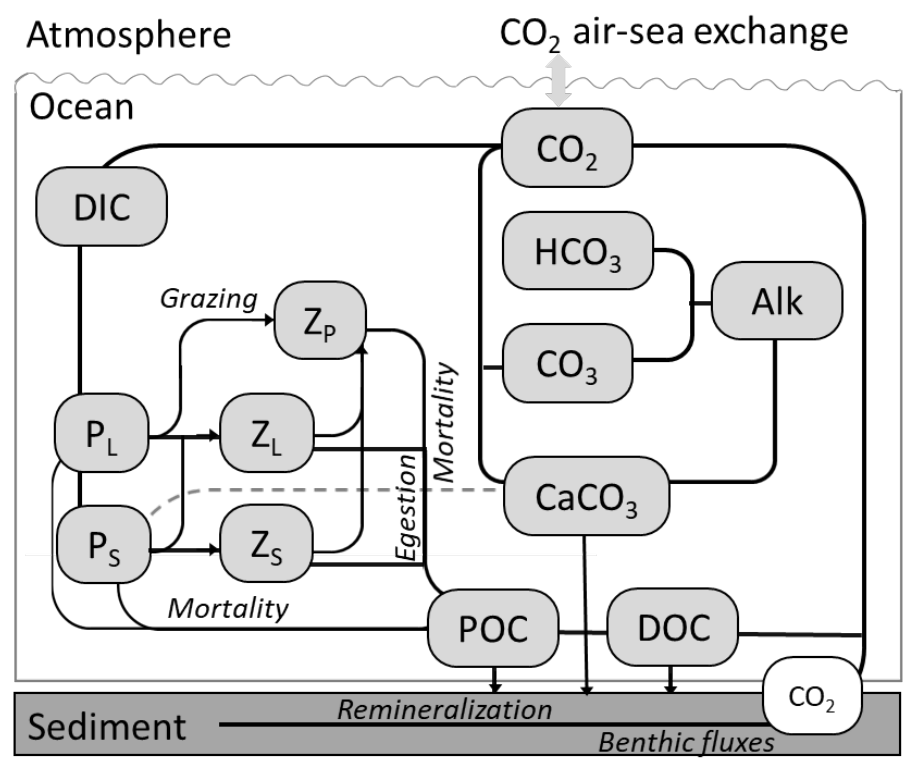

Figure 2: Schematic showing major processes incorporated in the carbon cycle.

We performed a 20-yr model hindcast covering the period of 1 January 2000 - 31 December 2019. The model setup was similar to that of Zang et al. (2020), with ocean physical initial and boundary conditions downscaled from the $1 / 12^{\circ}$ data assimilated Hybrid Coordinate Ocean Model (HYCOM/NCODA, GLBu0.08/expt_19.1, expt_90.9, expt_91.0, expt_91.1, expt_91.2, and expt_93.0 [https://www.hycom.org; Chassignet et al. 2003]). Atmospheric forcings include ground level or sea surface downwelling shortwave/longwave radiation, ground-level or sea surface upwelling shortwave/longwave radiation, surface air pressure, surface air temperature, relative humidity, precipitation, wind at $10 \mathrm{~m}$ were extracted from the NCEP Climate Forecast System Reanalysis (CFSR) (Saha et al. 2010) and Climate Forecast System Version 2 (CFSv2) (Saha et al. 2011). Boundary conditions of the biogeochemical variables (DIC, DOC, TA, $\mathrm{NO}_{3}, \mathrm{PO}_{4}, \mathrm{Si}, \mathrm{NH}_{3}$ are extracted from The Intergovernmental Panel on Climate Change (IPCC) CMIP6 global solution (CESM2-WACCM-FV2, historical, r1ilp1f1, nominal resolution $100 \mathrm{~km}$, [Danabasoglu, 2019]). Due to the global model ending in December 2014, the biogeochemical boundary condition of 2014 was used repeatedly for the period of 2015-2019. $\mathrm{O}_{2}$ is absent from the CESM2-WACCM-FV2 source, and is interpolated from the World Ocean Atlas 2018 (WOA18) product (Boyer et al, 2018; García et al., 2019). Freshwater and terrestrial nutrient inputs from 47 major rivers discharged to the GoM are applied as point sources. River discharge and water quality data of rivers in the U.S. are collected from US Geological Survey (USGS) stations (https://maps.waterdata.usgs.gov), river DOC is prescribed following the values reported by Shen et al. (2012), with additional reference from several other works (Reiman \& Xu, 2019; Stackpoole et al., 2017; Wang et al., 2013; Xu \& DelDuco, 2017). Mexican river discharge data are collected from BANDAS (https://www.gob.mx/conagua), water quality data of Mexican rivers is prescribed as the average of that of the Mississippi and Atchafalaya rivers. River nutrient and carbon load are reconstructed from available USGS observations. Missing river alkalinity values are interpolated from climatological values, 
https://doi.org/10.5194/bg-2021-339

Preprint. Discussion started: 17 December 2021

(c) Author(s) 2021. CC BY 4.0 License.

\section{(c) (i)}

and missing river DIC values are calculated from $\mathrm{pH}$ and alkalinity using the MATLAB program CO2SYS (Lewis \& Wallace, 1998). Validations of the model's performance in physics, nutrient cycle, and primary production can be found in Zang et al., 2019 and 2020. In this study, we focus on the model's performance in the carbon cycle, which is presented in the next section.

205 The simulation is set to start on 2000-01-01 and end in 2019-12-31. Since model simulated DIC concentration in the water column is sensitive to initial conditions (Hofmann et al., 2011; Xue et al., 2016), using initial condition from a snapshot (January 2000) of the global model result would be appropriate as the global model has been well stabilized up to the year 2000 from its "pre-industry" experiment. Nevertheless, we treated the first year of the simulation (2000) as the model spin-up, and all results presented below are based on model outputs from 2001 to 2019 unless otherwise specified. To quantify the impact from river discharge and global ocean on the carbon system in the GoM, in addition to the control experiment where the historical product of the CESM2-WACCM-FV2 experiment is applied as the boundary conditions (from here, experiment "His"), two perturbed experiments, "Bry" and "NoR" are added. The Bry experiment has a clamped DIC and TA conditions as that of the year 2000 for all following years while keeping all other experiment setups the same as that of the His. The NoR experiment eliminates the presence of all rivers in the model while keeping the rest of the experiment set up the same as that of the His. As by far most available observations are confined in the surface ocean, except for the GOMECC transects, in this study, we focus on the surface ocean carbon condition in the NGoM and Open GoM waters.

\section{Validation}

This section focus on the validation of the model results via comparison against autonomous mooring systems with surface $p \mathrm{CO}_{2}$ measurements, ship-based measurements from the Gulf of Mexico Ecosystems and Carbon Cruise transects (GOMECC, Barbero et al., 2019; Wanninkhof et al., 2013; Wanninkhof et al., 2016), and $\mathrm{pCO}_{2}$ underway measurements (data downloaded from https://www.ncei.noaa.gov/access/oads/). Direct observations of the GoM carbon system have been recognized as unbalanced among seasons due to fewer data points available in winter compared to other seasons. To overcome the sporadic direct measurement dataset, we also performed a model-data comparison against the remote sensing-based ML product of sea surface $\mathrm{pCO}_{2}$ by Chen et al. (2019).

\subsection{Model-buoy comparisons}

Temporal variability of sea surface $\mathrm{pCO}_{2}$ was recorded by the autonomous mooring system at two sites (CoastalMS and coastal LA) operated by the Atlantic Oceanographic and Meteorological Laboratory (AOML) of the National Oceanic and Atmospheric Administration (NOAA). The CoastalMS buoy site (location see Fig. 1, data coverage: 2009-01-14 to 2009-1209; 2011-03-17 to 2012-08-04; 2013-07-10 to 2014-02-10; 2014-02-10 to 2014-05-03; 2014-12-12 to 2015-03-22; 2015-0330 to 2016-09-22 2016-09-23 to 2017-05-29) is predominately impacted by the Mississippi River followed by the coastal ocean, whereas the CoastalLA buoy site (data coverage: 2017-07-14 to 2017-11-07; 2017-12-14 to 2019-04-26; 2019-06-04 
https://doi.org/10.5194/bg-2021-339

Preprint. Discussion started: 17 December 2021

(c) Author(s) 2021. CC BY 4.0 License.

(c) (i)

to $2020-08-12 ; 2020-08-12$ to $2021-08-25 ; 2021-08-25$ to 2021-11-29) is mutually influenced by the Mississippi River and the coastal ocean. The high-frequency measurements provide a time-resolved picture of year-round changing $\mathrm{pCO}_{2}$ values. Temperature and salinity can influence the chemical equilibrium in the carbonate system, therefore shifting the $\mathrm{pCO}_{2}$ values.

235 Validating the temperature and salinity at these two mooring sites is a prerequisite before looking into the surface $p \mathrm{CO}_{2}$ levels. In Fig. 3, the top four panels compare the sea surface temperature (SST) and salinity (SSS) between model and buoy measurements and show matching seasonal variability. At CoastalMS, the range for sea surface $p \mathrm{CO}_{2}$ is $150 \sim 600 \mu \mathrm{atm}$. Sea surface $\mathrm{pCO}_{2}$ records are more volatile at CoastalLA with a maximum value $>800 \mu$ atm and a minimum value around 150 $\mu \mathrm{atm}$. Following the salinity drop, $\mathrm{pCO}_{2}$ at the CoastalMS site is simultaneously reduced, demonstrating the river's influence on both salinity and $\mathrm{pCO}_{2}$. At CoastalLA, however, the $\mathrm{pCO}_{2}$ level does not necessarily follow the trend of salinity, implying complex controlling factors in addition to the river inputs. The bottom two panels of Fig. 3 show a good agreement between measured and simulated sea surface $\mathrm{pCO}_{2}$. We notice model-data discrepancies in April 2018-04 at CoastalLA and July 2011 at CoastalMS and ascribe such bias to the uncertainty in the riverine DIC inputs prescription and the limited model horizontal resolution $(\sim 5 \mathrm{~km})$.
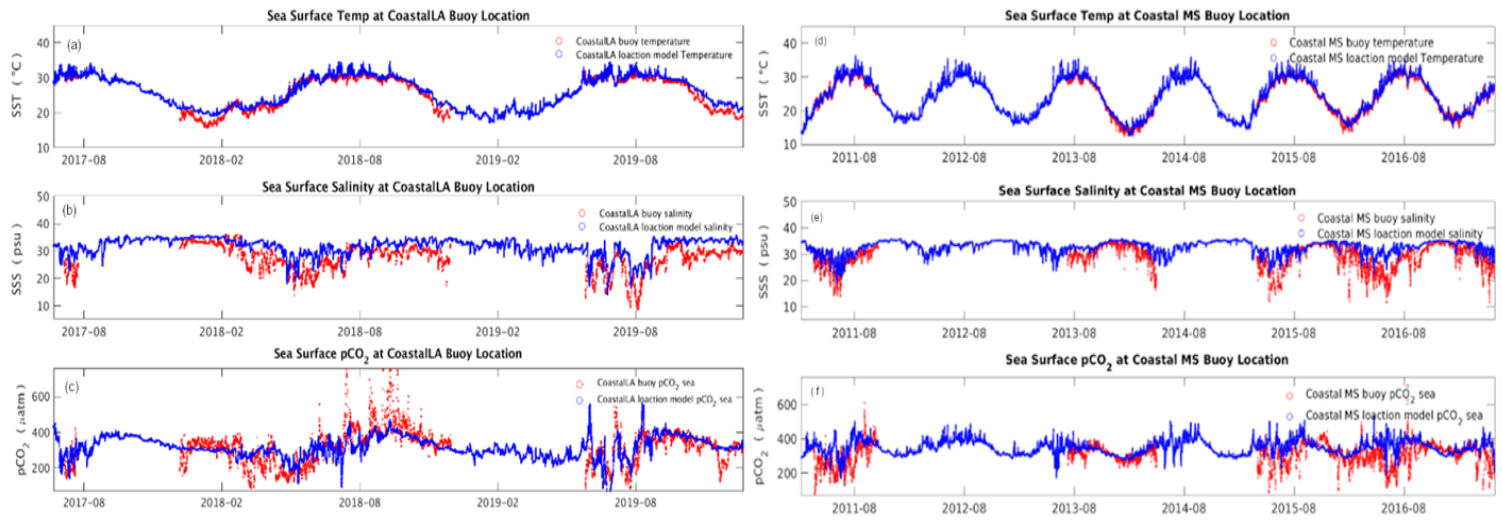

Figure 3: Timeseries of SST, SSS, and $\mathrm{pCO}_{2} \_$sea at site CoastalLA and CoastalMS.

\subsection{Model-cruise comparisons}

Cruise carbon measurements include underway water $\mathrm{pCO}_{2}$ data and conductivity-temperature-depth (CTD) bottle results.

250 We compare the model result at the LA transect with the observations of GOMECC cruises, conducted at the same location during GOMECC1 in 2007, GOMECC2 in 2012, and GOMECC in 2017, respectively. Measurements of TA during GOMECC cruises followed Dickson's definition (1981), where the TA is expressed as Eq. (3)

$$
\begin{aligned}
\mathrm{TA}= & {\left[\mathrm{HCO}_{3}{ }^{-}\right]+2\left[\mathrm{CO}_{3}{ }^{2-}\right]+\left[\mathrm{B}(\mathrm{OH})_{4}{ }^{-}\right]+\left[\mathrm{OH}^{-}\right]+\left[\mathrm{HPO}_{4}{ }^{2-}\right]+2\left[\mathrm{PO}_{4}{ }^{3-}\right]+} \\
& {\left[\mathrm{H}_{3} \mathrm{SiO}_{4}{ }^{-}\right]+\left[\mathrm{NH}_{3}\right]+\left[\mathrm{HS}^{-}\right]-\left[\mathrm{H}^{+}\right]-\left[\mathrm{HSO}_{4}{ }^{-}\right]-[\mathrm{HF}]-\left[\mathrm{H}_{3} \mathrm{PO}_{4}\right]-\left[\mathrm{HNO}_{2}\right] }
\end{aligned}
$$


https://doi.org/10.5194/bg-2021-339

Preprint. Discussion started: 17 December 2021

(c) Author(s) 2021. CC BY 4.0 License.

(c) (1)

255 Equation (3) contains fourteen variables, among which $\left[\mathrm{PO}_{4}{ }^{3-}\right]$ are explicitly modeled as active tracers, $\left.\left[\mathrm{HCO}_{3}{ }^{-}\right],\left[\mathrm{CO}_{3}{ }^{2-}\right],[\mathrm{B(OH})_{4}{ }^{-}\right],\left[\mathrm{OH}^{-}\right],\left[\mathrm{HPO}_{4}{ }^{2-}\right],\left[\mathrm{H}_{3} \mathrm{SiO}_{4}{ }^{-}\right],\left[\mathrm{H}^{+}\right],[\mathrm{HF}],\left[\mathrm{H}_{3} \mathrm{PO}_{4}\right]$ are calculated by the carbon module, and $\left[\mathrm{HS}^{-}\right],\left[\mathrm{HSO}_{4}{ }^{-}\right],\left[\mathrm{HNO}_{2}\right],\left[\mathrm{NH}_{3}\right]$ are unaccounted. Figure 4 shows the vertical profiles of observed DIC, TA, and their ratio collected at the LA transects $\left(-90^{\circ} \mathrm{W}, 27.5^{\circ} \mathrm{N}-29.1^{\circ} \mathrm{N}\right.$, shown in Fig.1) overlaid with the model solution. All three transects were taken during August when nutrient supply from the MARS was high. Model simulated profiles at the transects match well with the in situ CTD data. Relative low surface DIC concentration $\left(<2150 \mathrm{mmol} \mathrm{m}^{-3}\right)$ above $200 \mathrm{~m}$ isobath demonstrates the river's influence in NGoM. The general increasing trend of DIC with depth confirms the presence of a biological pump, where inorganic carbon is utilized during photosynthesis in the euphotic layer. Subsequently, the generated OM sinks into deeper waters while being remineralized along the way. The TA profiles show more variation compared with DIC, where generally a lower TA concentration $\left(<2380\right.$ millequivalent $\left.\mathrm{m}^{-3}\right)$ could be found at the surface as the direct dilution from river 265 discharge, follow by a quick increase to $\sim 2380$ millequivalent $\mathrm{m}^{-3}$ in the euphotic layer due to the active photosynthetic activities, which generate alkalinity. Further deep, the TA profiles show a decreasing trend between 200 and $700 \mathrm{~m}$, which could be explained by the water column respiration and nitrification. The TA profiles show a slow increase from $800 \mathrm{~m}$ and deeper, which coincides with the alkalinity generation processes in sediment and possibly dissolution of carbonate minerals, both adding to the bottom water TA. The TA/DIC ratio has a maximum at the surface due to low DIC concentration and decreases with depth as DIC concentration increased. 
https://doi.org/10.5194/bg-2021-339

Preprint. Discussion started: 17 December 2021

(c) Author(s) 2021. CC BY 4.0 License.
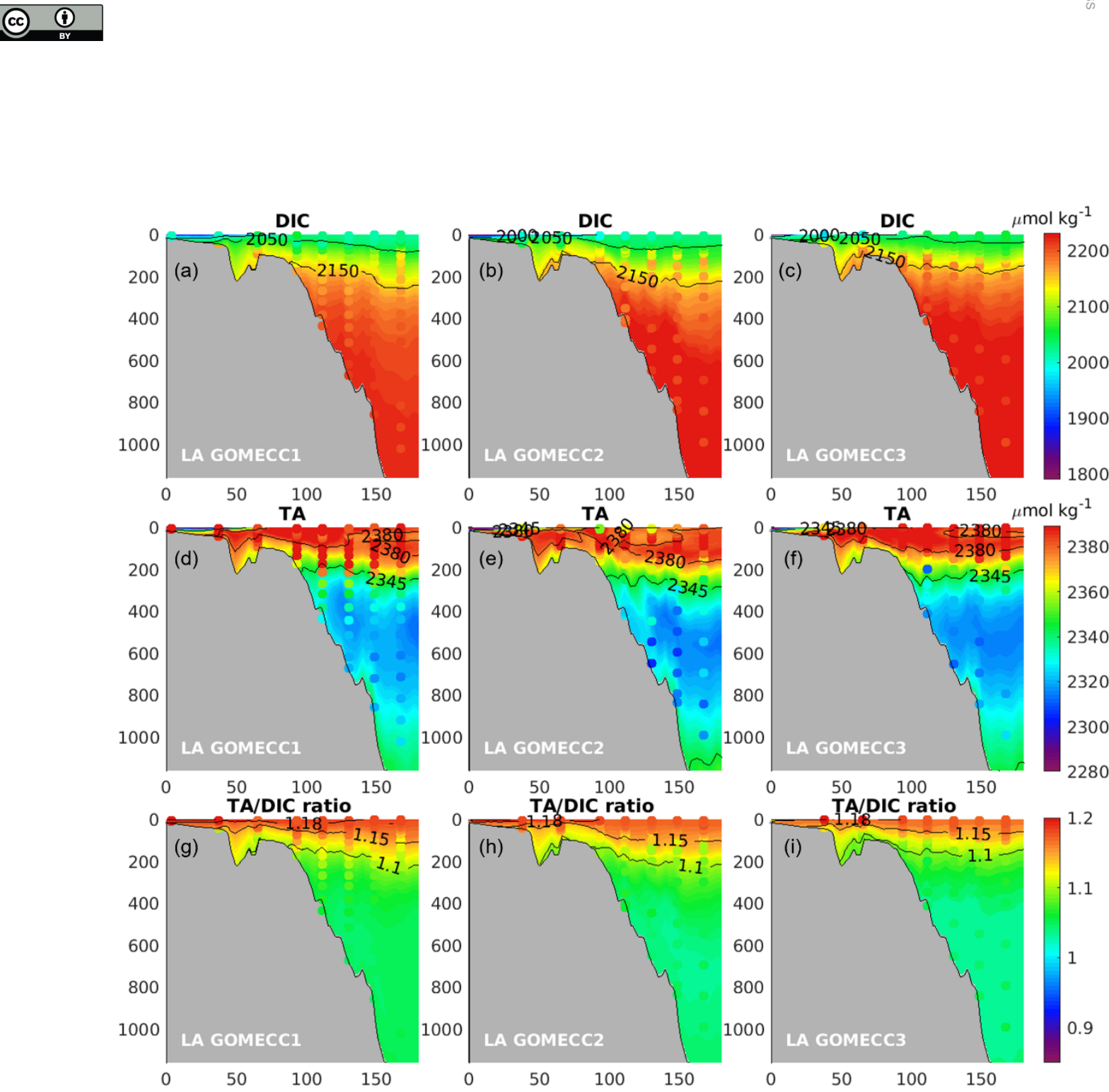

Figure 4: Discrete measurement of DIC, TA along the LA transect during GOMECC1, GOMECC2, and GOMECC3 cruises shown as scattered dots, compared with model results in color contour, with the water depth shown on the left side of each figure in meter.

\subsection{Model-ML $\mathrm{pCO}_{2}$ product comparisons}

Direct comparison between cruise measurement of ocean surface $\mathrm{pCO}_{2}$ and daily averaged model result might suffer from systematic bias due to the sparsity of curies data, both temporally and spatially. The ML model generates surface $\mathrm{pCO}_{2}$ from Chen et al. (2019) integrated $>220$ cruise surveys between 2002-2019 and MODIS ocean color product covering 2002-2017. Comparison between the two surface $\mathrm{pCO}_{2}$ products are shown in Fig. 5, where surface $\mathrm{pCO}_{2}$ results from Chen et al. (2019) 280 are denoted as "ML" and results from this work are denoted as "Model" for the monthly climatology from July 2002 to December 2017. The two results exhibit a highly similar spatial distribution of surface $\mathrm{pCO}_{2}$, with our model result 
https://doi.org/10.5194/bg-2021-339

Preprint. Discussion started: 17 December 2021

(c) Author(s) 2021. CC BY 4.0 License.

demonstrating substantial influence from the Loop Current. Compared with the ML model, our model produces lower $\mathrm{pCO}_{2}$ estimates over $\mathrm{NGoM}$ during winter and fall, higher $\mathrm{pCO}_{2}$ estimates over WF during summer, and stronger influence from the Caribbean Sea. Chen et al. (2019) reported that no satellite data was found for $\mathrm{pCO}_{2}<145 \mu \mathrm{atm}$ or $>550 \mu$ atm during their model development. This can also be a factor when considering the differences between the two products.

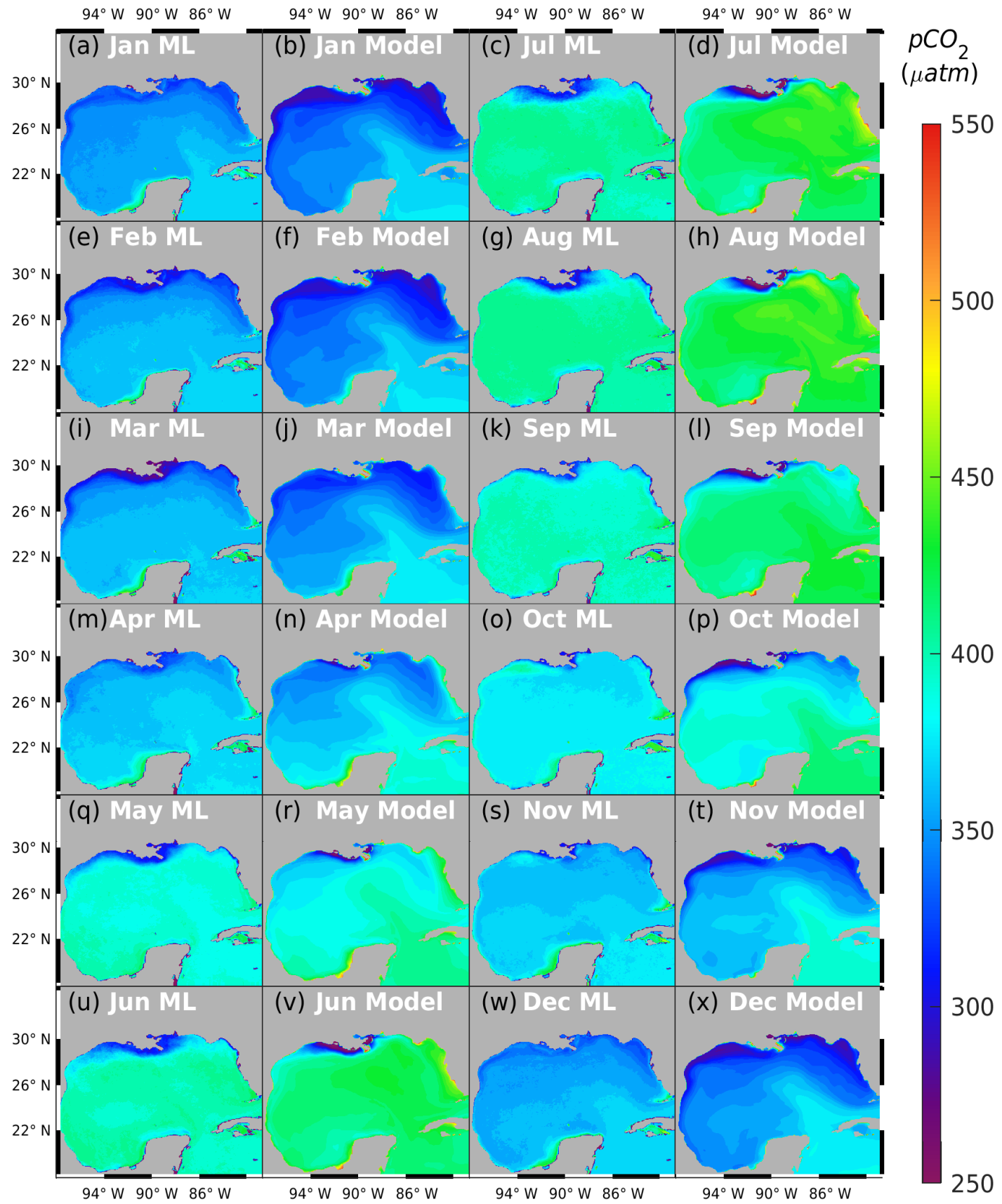

Figure 5: Comparison of surface $\mathrm{pCO}_{2}$ between ML model (Chen et al, 2019) and this work. 
https://doi.org/10.5194/bg-2021-339

Preprint. Discussion started: 17 December 2021

(c) Author(s) 2021. CC BY 4.0 License.

(c) (i)

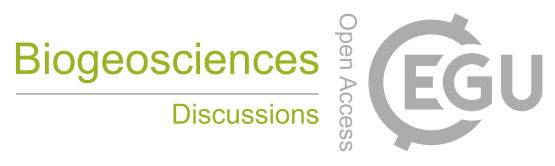

Besides buoy records, transects, and the ML products, we also perform an extensive model-data comparison using available ship-based underway $\mathrm{pCO}_{2}$ measurements from the Ocean Carbon and Acidification Dataset

290 (https://www.ncei.noaa.gov/access/oads/). Our model can capture both spatial and temporal variability in the underway $p \mathrm{CO}_{2}$ dataset as well (Fig. S1 and Fig. S2). These extensive model-data comparisons give us the confidence that our model, driven by carbon boundary conditions from the global model, can reproduce temporal, spatial, and vertical variability of the $\mathrm{CO}_{2}$ dynamics in the GoM.

\section{Result}

295 In this section, we present the spatial and temporal pattern of key carbon system variables, namely $p \mathrm{CO}_{2}, \mathrm{pH}, \Omega$, and air-sea $\mathrm{CO}_{2}$ flux simulated over the past 20 years in the GoM. In this study, we emphasize the surface carbon condition in two regions: NGoM and Open GoM, where most existing in situ data are distributed. We perform a linear fit of the time series of the key carbon system variables in each region and show the fitted relationships in Fig. 6. The slopes of the fitted linear plot give estimations on the change rate of each carbon variable over the past two decades. 
https://doi.org/10.5194/bg-2021-339

Preprint. Discussion started: 17 December 2021

(c) Author(s) 2021. CC BY 4.0 License.

(c) (i)

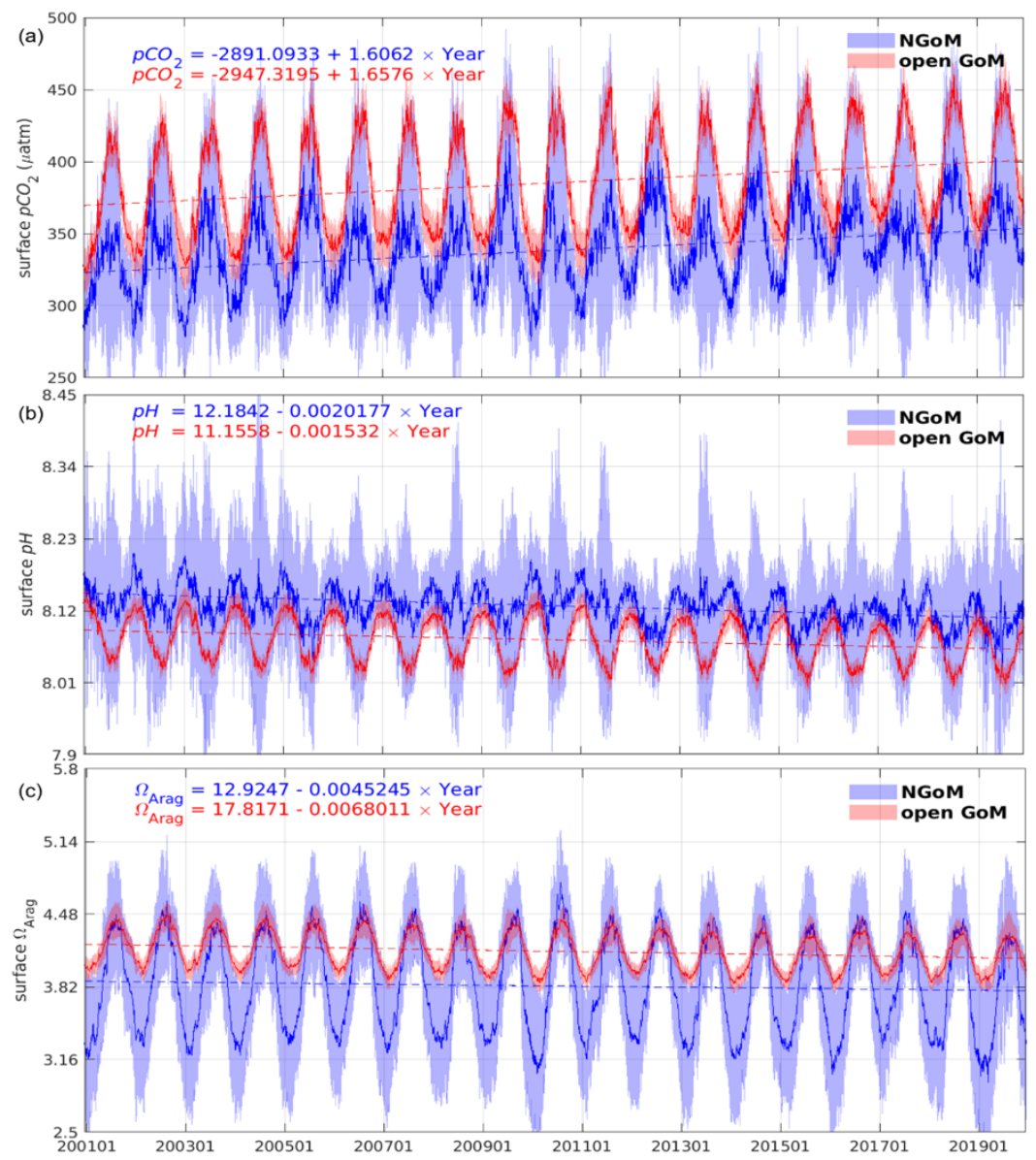

Figure 6: Time series and trend analysis of sea surface (a) $\mathrm{pCO}_{2}$, (b) $p H$, (c) $\Omega_{\mathrm{Arag}}$ for NGoM (blue), Open GoM (red). Solid lines depict the daily spatial mean value; shaded areas stand for $1 \sigma$ standard deviation, dash lines trace the linear fit of the time series.

\section{$4.1 \mathrm{pCO}_{2}$}

We simulate a generally increasing trend in surface $\mathrm{pCO}_{2}$ level for both $\mathrm{NGoM}$ and Open GoM, with an increasing rate of 1.61 $\mu \mathrm{atm} \mathrm{yr}^{-1}$ and $1.66 \mu \mathrm{atm} \mathrm{yr}^{-1}$, respectively (Fig. 6). Seasonal ocean surface $\mathrm{pCO}_{2}$ variation is primarily affected by temperature variations. To evaluate the $\mathrm{pCO}_{2}$ trend without temperature effects, we decouple the thermal and nonthermal components of $p \mathrm{CO}_{2}$ at the ocean surface using Eq. (4) and (5) and further extract the $\mathrm{pCO}_{2}$ variation due to gross primary production and airsea $\mathrm{CO}_{2}$ flux. The temperature sensitivity of $\mathrm{CO}_{2}, \gamma_{\mathrm{T}}=4.23 \%$ per degree Celsius, proposed by Takahashi et al. (1993), is used to perform the thermal decoupling by multiplying the mean $\mathrm{pCO}_{2}$ value with SST induced difference described in Eq. (4). The nonthermal counterpart is obtained by removing the thermal effect from the $\mathrm{pCO}_{2}$ time series using Eq. (5). $p \mathrm{CO}_{2}$ variations due to gross primary production are estimated from the carbon module based on the DIC consumed by gross primary production and denoted as $\mathrm{pCO}_{2}{ }^{G P P} \cdot \mathrm{pCO}_{2}$ variations due to air-sea $\mathrm{CO}_{2}$ flux are calculated from the carbon module based on the DIC change from the air-sea exchange and denoted as $\mathrm{pCO}_{2}{ }^{\text {flux }}$. 


$$
\begin{gathered}
p \mathrm{CO}_{2}{ }^{\text {th }}=<p \mathrm{CO}_{2}>\exp \left(\gamma_{T} \cdot(S S T-<S S T>)\right) \\
p \mathrm{CO}_{2}{ }^{n t}=p C \mathrm{O}_{2} \cdot \exp \left(\gamma_{T} \cdot(<S S T>-S S T)\right)
\end{gathered}
$$

Figure 7 shows the seasonal and spatial patterns of four decoupled $\mathrm{pCO}_{2}$ components, namely the $\mathrm{pCO}_{2}{ }^{\text {th }}, \mathrm{pCO}_{2}{ }^{n t}, \mathrm{pCO}_{2}{ }^{G P P}$, and $\mathrm{pCO}_{2}{ }^{\text {flux }}$. The $\mathrm{pCO}_{2}{ }^{\text {th }}$ patterns in the top row (a)(b)(c)(d) of Fig. 7 reflect the fluctuation of $p \mathrm{CO}_{2}$ due to thermal effects. Over the four seasons, a general pattern of rising $\mathrm{pCO}_{2}{ }^{\text {th }}$ from spring to summer and a gradual reduction from summer onwards can be observed. The NGoM shelf exhibits the lowest $\mathrm{pCO}_{2}{ }^{\text {th }}$ values during winter, while WF shows elevated $\mathrm{pCO}_{2}{ }^{\text {th }}$ values during summer. The higher $\mathrm{pCO}_{2}^{\text {th }}$ values dwelling in the southern part of the Yucatan shelf reveal the warm water flowing into the GoM from the Caribbean Sea. The second row $(\mathrm{e})(\mathrm{f})(\mathrm{g})(\mathrm{h})$ of Fig. 7 shows the nonthermal component of $p \mathrm{CO}_{2}$. The relatively high $\mathrm{pCO}_{2}{ }^{n t}$ during winter on the NGoM shelf, compared to that of the Open GoM, shows the strong solvation effect of $\mathrm{CO}_{2}$ with low SST, contributing to a high DIC/TA ratio and strong carbon uptake. The lower two rows of Fig. 7 show $p \mathrm{CO}_{2}$ changes due to the gross primary production and $\mathrm{CO}_{2}$ air-sea exchange, respectively. The $\mathrm{pCO}_{2}{ }^{G P P}$ reflects the intensity of primary production in terms of $\mathrm{pCO}_{2}$ reduction. $\mathrm{pCO}_{2}{ }^{G P P}$ has larger magnitudes in NGoM during spring and summer and is gradually attenuated during and after fall. The large magnitudes of $\mathrm{pCO}_{2}{ }^{G P P}$ during summer in NGoM waters and Open GoM region following the extension of MARS plume, suggesting strong biological $\mathrm{CO}_{2}$ removal in those regions. These results show that gross primary production has a stronger regulation on surface $\mathrm{pCO}_{2}$ during spring and summer in river-dominated waters and upwelling regions. While a minor contribution from gross primary production can be seen during winter, on the flat and shallow WF, and in Open GoM regions southern of Loop Current. The $\mathrm{pCO}_{2}{ }^{\text {flux }}$ reflects the intensity of air-sea $\mathrm{CO}_{2}$ exchange attempting to mitigate the air-sea disequilibrium caused by local physical and biological processes. The relatively high value of $\mathrm{pCO}_{2}{ }^{n t}$ and low magnitude of $\mathrm{pCO}_{2}{ }^{G P P}$, as well as low river discharge (minimal river water mixing) in the WF during winter, indicate a strong $\mathrm{CO}_{2}$ uptake from the atmosphere due to low SST. This analysis agrees with the low $\mathrm{pCO}_{2}^{\text {th }}$ and the high $\mathrm{pCO}_{2}{ }^{\text {flux }}$ values in the WF during winter shown in Fig. 7(d)(p). Situations during seasons other than winter are more complicated due to active biological activities and mixing. The Mississippi delta region has a high $\mathrm{pCO}_{2}{ }^{\text {th }}$ value during summer, however, combined with effects of mixing and strong primary production (large magnitude of $\mathrm{PCO}_{2}{ }^{G P P}$ ), this region acts as a strong carbon sink that exhibits a high value of $\mathrm{pCO}_{2}{ }^{\text {flux }}$ compensated from the atmosphere. Figure 7 demonstrates that most of the time around the year, the surface $\mathrm{pCO}_{2}$ pattern is not dominated by a single factor but a synthesis of multiple controlling processes. The result of $\mathrm{pCO}_{2}$ decomposition agrees with the current view of the $\mathrm{pCO}_{2}$ dynamic and carbon uptake patterns in the GoM, which is strong carbon uptake during winter due to thermal effect and high biological $\mathrm{CO}_{2}$ drawdown during spring and summer under the riverine influence. 


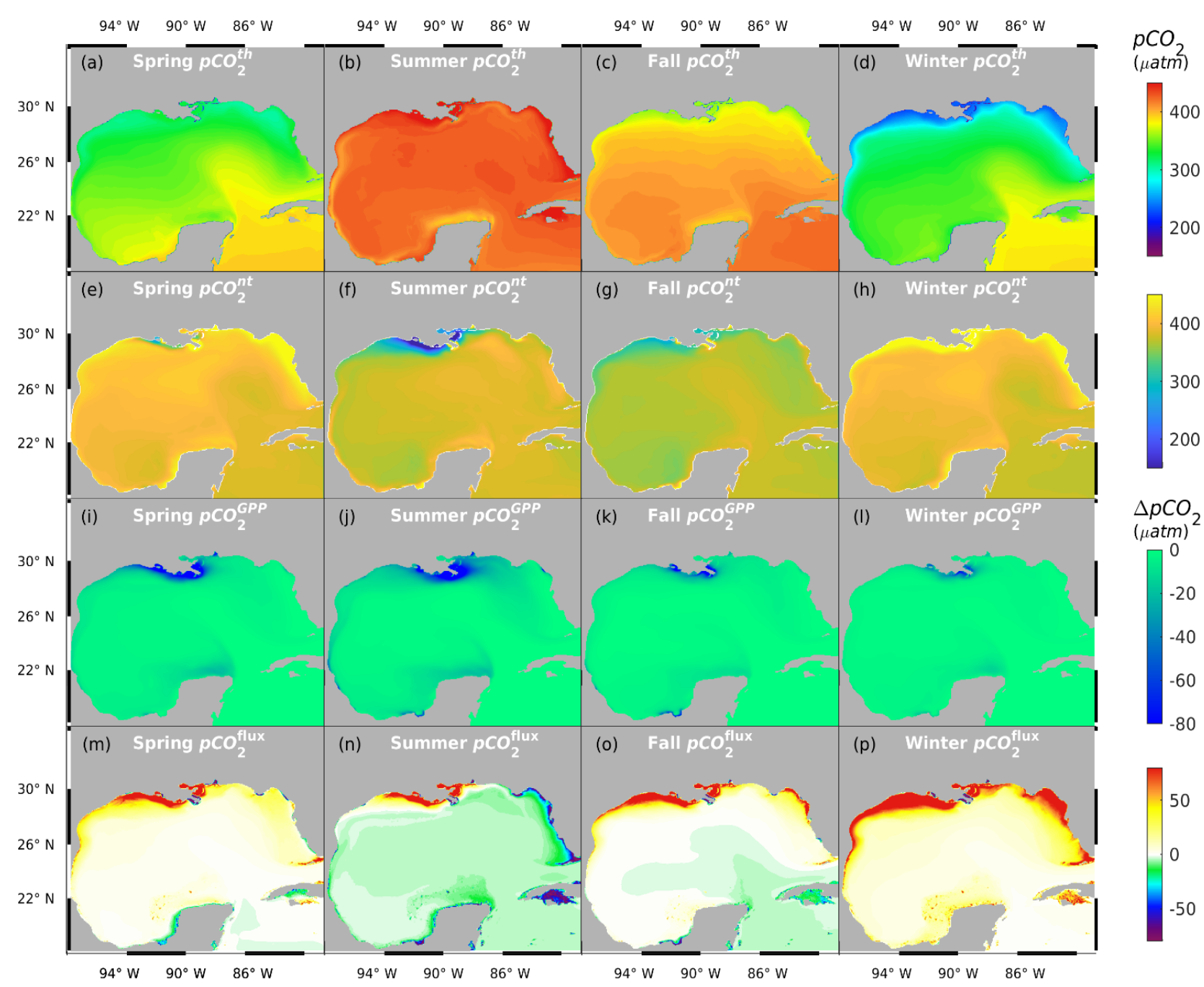

Figure 7: Spatial distribution of sea surface $\mathrm{pCO}_{2}$ over four seasons. From the top row to bottom row: $p \mathrm{CO}_{2}{ }^{\text {th }}, \mathrm{pCO}_{2}{ }^{\text {nt }}, \mathrm{pCO}_{2}{ }^{\mathrm{GPP}}$, $\mathrm{pCO}_{2}^{\text {flux }}$

\section{$4.2 \mathrm{pH}$}

Ocean surface $p H$ in the GoM shows a clear decreasing trend, with a $0.0020 \mathrm{yr}^{-1}$ decrease over the NGoM region and a 0.0015 $\mathrm{yr}^{-1}$ decrease over the Open GoM region. Figure 8 shows the seasonal pattern of ocean surface $p H$ over the GoM. Spatial and seasonal $p H$ patterns show larger variation over the NGoM, especially on the inner shelf $(\operatorname{depth}<50 \mathrm{~m})$. The $p H$ level in the surface water is closely associated with temperature, photosynthetic activities, and water mixing. The high $p H$ value on the NGoM shelf reveals the strong influence of riverine alkalinity export and nutrient-stimulated primary production. The lower $p H$ values on the WF shelf during summer and the generalized greater $p H$ values over NGoM during winter demonstrate the high $p H$ sensitivity on SST. The upwelling region along the west Yucatan shelf shows reduced $p H$ values all year round compared with its surrounding waters. The upwelling along the WGoM slope has a similar effect of reducing and maintaining 
a relatively low $p H$, effectively forming a $p H$ boundary between the shelf water and the Open GoM. The Open GoM is largely dominated by the warmer and lower $p H$ water from the Caribbean Sea throughout the year.

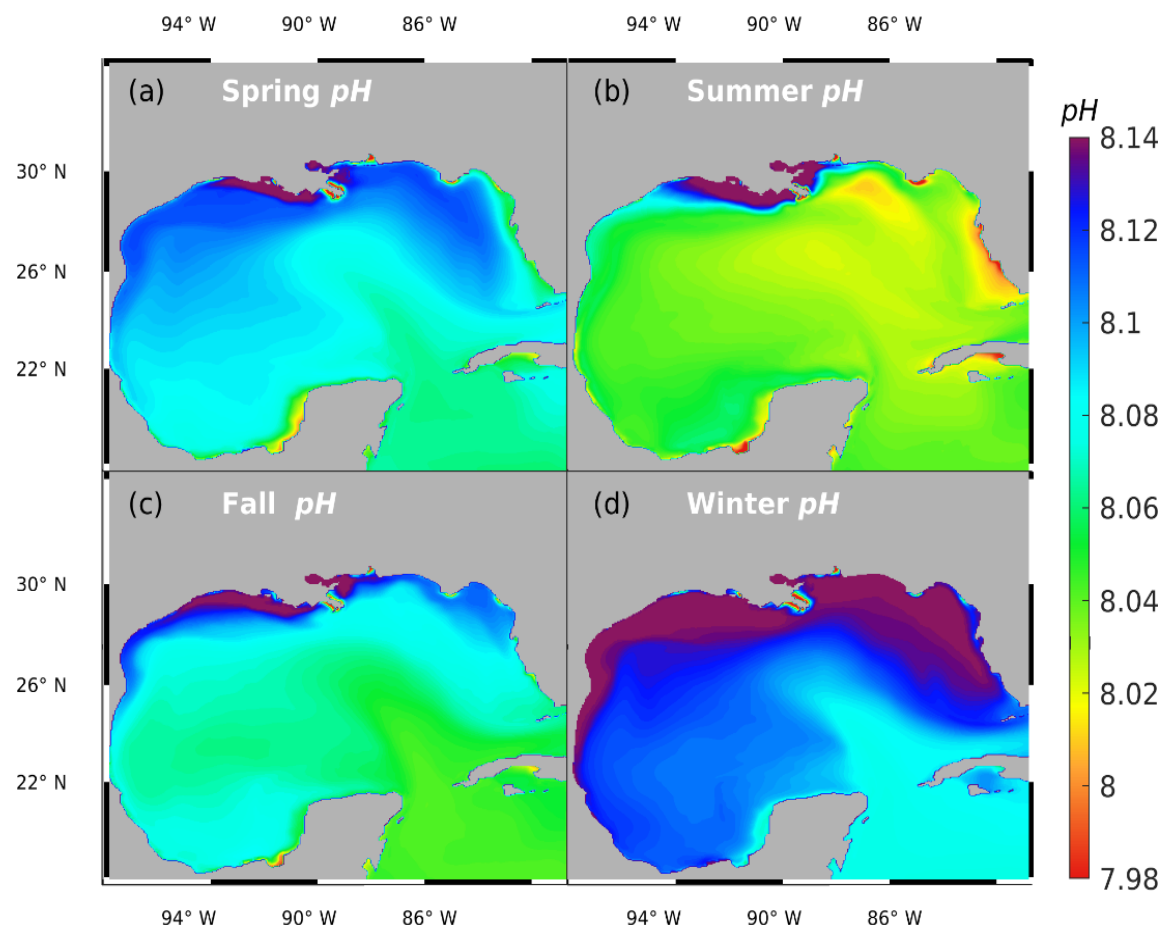

Figure 8: Seasonal averaged sea surface $p H$ over 2001-2019

\subsection{Aragonite and Calcite Saturation State}

Aragonite undersaturation occurs $\left(\left[\mathrm{CO}_{3}^{2-}\right]<66 \mu \mathrm{mol} \mathrm{kg}{ }^{-1}\right)$ before calcite undersaturation $\left(\left[\mathrm{CO}_{3}^{2-}\right]<42 \mu \mathrm{mol} \mathrm{\textrm {kg } ^ { - 1 }}\right)\left(\mathrm{Feely}^{2-}\right.$ Doney, \& Cooley, 2009; Feely et al, 2002), as a result, $\Omega_{\text {Calc }}$ is approximately $50 \%$ higher than $\Omega_{\text {Arag }}$ and their spatial and seasonal variations are very similar as shown in Fig. 9. Variations in temperature, alkalinity, and $\mathrm{pCO}_{2}$ impose important controls on $\Omega_{\text {Arag. }}$. The multiyear variability of $\Omega_{\text {Arag }}$ at the ocean surface is shown in Fig. 6(c). The NGoM region shows a smaller decreasing trend in $\Omega_{\text {Arag }}\left(0.0045 \mathrm{yr}^{-1}\right)$ compared to that of Open GoM $\left(0.0068 \mathrm{yr}^{-1}\right)$. Noted the data contained in Fig. 6 does not include water from the shallow shelf waters (water depth $<10 \mathrm{~m}$ ), therefore the trend in NGoM does not incorporate the condition in coastal estuaries. The spatial distribution of $\Omega_{\text {Arag }}$ across the GoM depicts a healthy level of $\Omega$ and a low risk of ocean acidification (Fig. 9). While the coastal ocean generally has a relatively high $\Omega$ level, some coastal locations warrant special attention when evaluating their tendency towards calcium mineral dissolution. These locations include coastal regions that experience a large load of riverine OM inputs (e.g., the Mississippi River delta in summer) and the upwelling regions that receive relatively higher acidity water from the bottom ocean (e.g., west of Yucatan). These regions show significant $\Omega$ reductions compared to the surrounding waters and are the potential primary victim of ocean acidification. The influence from the river on $\Omega$ is complex, on one hand, a high nutrient level of river discharge could stimulate a high photosynthetic rate which consumes DIC and increases $\Omega$, on the other hand, photosynthesis favors calcification which consumes carbonate ion and 
reduces $\Omega$. Therefore, $\Omega$ is subject to increase with stronger photosynthesis and decrease with stronger calcification. Therefore the magnitude of the overall effect will depend upon photosynthetic rates and the calcification rate. In this work, two phytoplankton groups are modeled, diatom (silicifying), and small phytoplankton (implicitly include the calcifying coccolithophores, foraminifera, and dinoflagellates), of which only the small phytoplankton group has the potential to conduct calcification (Raven \& Giordano, 2009). Besides being regulated by temperature and small phytoplankton concentration, the calcification rate also depends on the composition of the phytoplankton population. The small phytoplankton group has a survival advantage at relatively low nitrogen concentrations and could be grazed by two zooplankton groups (mesozooplankton and micro-zooplankton), whereas diatom is more nutrient-demanding and can be grazed by three zooplankton groups (predator zooplankton, meso-zooplankton, and micro-zooplankton). The competitive phytoplankton evolution shaped the relative rates between photosynthesis and calcification on the NGoM shelf during summer. The reduced $\Omega$ to the east of the Mississippi River delta is a combined result from high DIC water entrained by Loop Current eddies west of the delta, and an increased ratio of small phytoplankton in offshore waters.

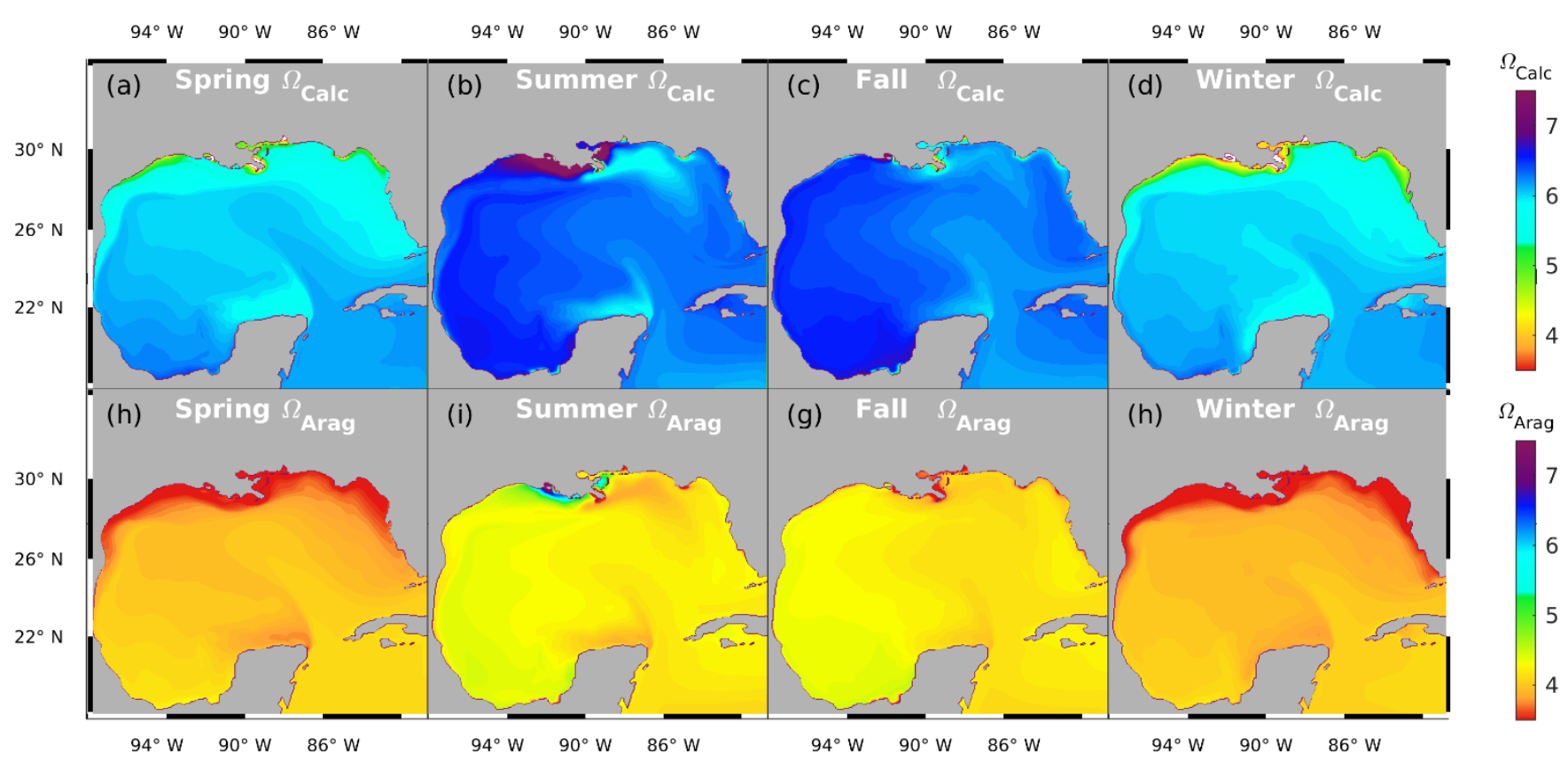

Figure 9: Seasonal mean sea surface $\Omega_{\text {Arag }}$ and $\Omega_{\text {Calc }}$ over 2001-2019

\subsection{Air-sea $\mathrm{CO}_{2}$ Flux}

Air-sea $\mathrm{CO}_{2}$ flux is calculated from daily averaged model data over 2001 to 2019 (Table 2). The GoM overall is a $\mathrm{CO}_{2}$ sink 390 with a mean flux rate of $0.62 \mathrm{~mol} \mathrm{C} \mathrm{m}^{-2} \mathrm{yr}^{-1}\left(11.77 \mathrm{Tg} \mathrm{C} \mathrm{yr}^{-1}\right)$, which is commensurate with the reported value of $11.8 \mathrm{Tg} \mathrm{C}$ $\mathrm{yr}^{-1}$ by Coble et al. (2010). The greatest carbon uptake rate occurs in winter $\left(1.97 \mathrm{~mol} \mathrm{C} \mathrm{m}^{-2} \mathrm{yr}^{-1}\right)$, while the weakest carbon uptake is present during fall $\left(0.16 \mathrm{~mol} \mathrm{C} \mathrm{m}^{-2} \mathrm{yr}^{-1}\right)$. The strongest carbon efflux is simulated in summer $\left(-0.57 \mathrm{C} \mathrm{m}^{-2} \mathrm{yr}^{-1}\right)$. On 
https://doi.org/10.5194/bg-2021-339

Preprint. Discussion started: 17 December 2021

(c) Author(s) 2021. CC BY 4.0 License.

\section{(c) (i)}

average, water in the NGoM acts as a sink throughout the years, and the water in the Open GoM acts as a weak source during summer (and fall for 2002, 2004, 2006, and 2009) and a sink during the rest of the year. The direction and magnitude of the air-sea exchange can be seen in Fig. 10, where a positive number indicates the ocean is a carbon sink. The NGoM is a very strong $\mathrm{CO}_{2}$ sink year-round and Open GoM is a source of $\mathrm{CO}_{2}$ during summer but a sink in the rest of the year (except during fall in a few years), as shown in Fig. 10(b). There are clear trends and patterns on multiyear $\mathrm{CO}_{2}$ air-sea flux as shown in Fig. 10(a), where greater air-sea $\mathrm{CO}_{2}$ flux average could be seen at the end of 2019 than that of 2001, resulting in a stronger carbon sink in both regions. A significant anomaly in the middle part of the record (2009-2011) can be observed, which could result from the influence of a large negative North Atlantic Oscillation (NAO) and El Niño in 2010 (Buchan et al., 2014). Similar observations in the Caribbean Sea are attributed to the single-year anomalies in the climate indices and the climate mode teleconnection (Wanninkhof et al., 2019).

In the last three rows of Table 2, the annual air-sea $\mathrm{CO}_{2}$ flux is listed together with that reported by Xue et al. (2016) for 20052010, Robbins et al. (2014) for 1996-2012, and Gomez et al. (2020) for 2005-2014. In this study, the $\mathrm{CO}_{2}$ air-sea flux is calculated with a timestep of $240 \mathrm{~s}$, and output in the form of a daily average. The gas transfer velocity coefficient of $0.31 \mathrm{~cm}$ $\mathrm{h}^{-1}$ is used in Eq. (2). Using the same gas transfer velocity parameterization with this study, Xue et al. (2016) simulated a smaller carbon sink estimation in NGoM and a larger carbon sink estimation in the Open GoM due to their overestimation of shelf $\mathrm{pCO}_{2}$ and underestimation of Open GoM $\mathrm{pCO}_{2}$, which is likely resulted from the over-simplified prescription of the initial and boundary condition of DIC and TA (based on the empirical relationship with temperature and salinity). To compare with the flux estimates of Gomez, et al. (2020), we rescale our estimates to the gas transfer velocity parameterization used in their work (Wanninkhof, 2014) and produced mean estimations of 1.59, 0.52, $0.50 \mathrm{~mol} \mathrm{~m}^{-2} \mathrm{yr}^{-1}$ for NGoM, Open GoM and Gulf-wide, respectively. Gomez et al. (2020) simulate smaller carbon sink values possibly due to the overestimation in NGoM shelf surface $\mathrm{pCO}_{2}$ (especially near the MARS plume region and WF, the model-data discrepancy can be viewed in the

415 supporting information Fig. S6 in their paper). The observation-based studies by Huang et al. (2015) yielded an annual sink of $0.96 \pm 3.7 \mathrm{~mol} \mathrm{C} \mathrm{m}^{-2} \mathrm{yr}^{-1}$, based on the monthly satellite products QuikSCAT wind data (12.5 km resolution). Lohrenz et al. (2018) estimated an annual sink of $1.1 \pm 0.3 \mathrm{~mol} \mathrm{C} \mathrm{m}^{-2} \mathrm{yr}^{-1}$, using gas transfer velocities estimated for each 8-day period. These two observation-based studies suggest a larger carbon sink than previous model work and are more consistent with the estimation of this work. Another reason that this study estimated a stronger air-sea flux is because previously reported values are based on an earlier timespan when the ocean was a weaker carbon sink due to a relatively low atmospheric $\mathrm{pCO}_{2}$ compared with more current conditions. After comparing with multiple sources, we believe the air-sea $\mathrm{CO}_{2}$ flux estimated in this work is more reliable than previous GoM model studies. 
https://doi.org/10.5194/bg-2021-339

Preprint. Discussion started: 17 December 2021

(c) Author(s) 2021. CC BY 4.0 License.

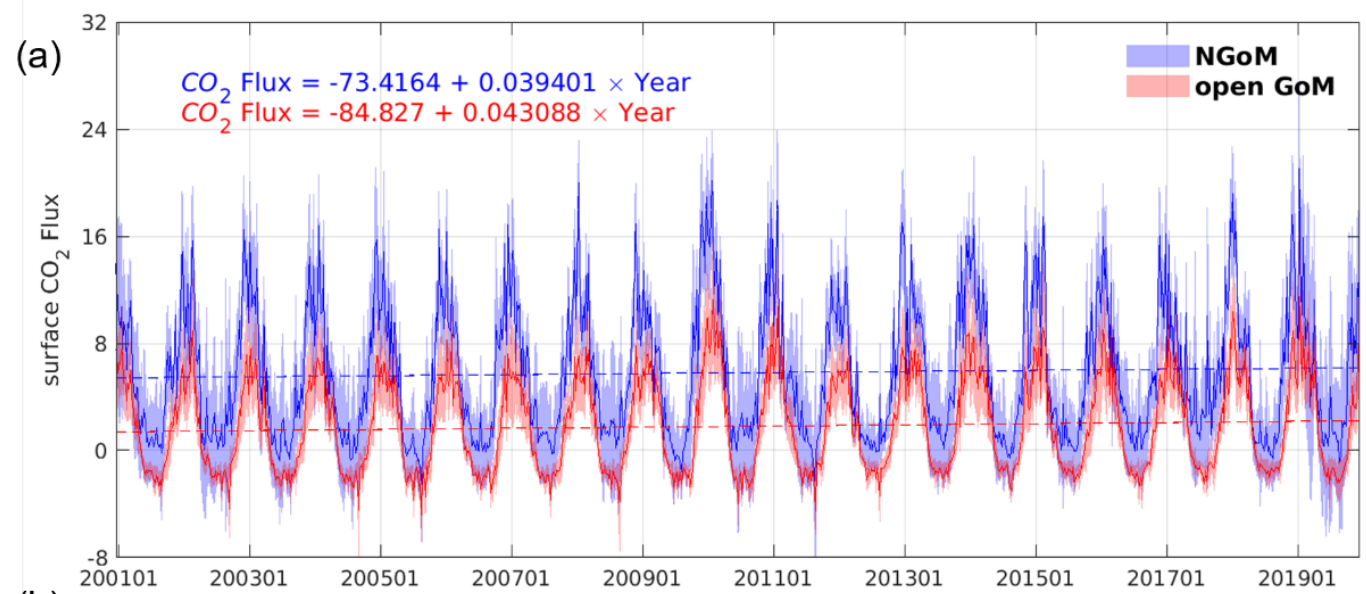

(b)

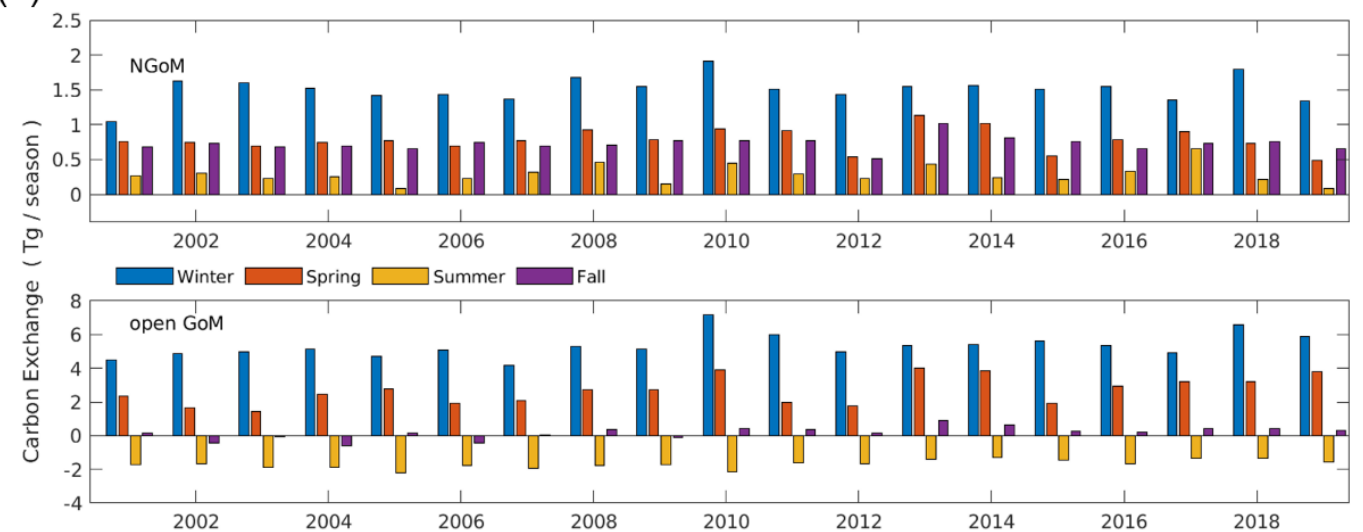

Figure 10: Air-sea $\mathrm{CO}_{2}$ exchange over GoM: a) multiyear $\mathrm{CO}_{2}$ flux regression over the weekly mean levels in NGoM and Open GoM; b) seasonal $\mathrm{CO}_{2}$ air-sea exchange budget over two decades in NGoM and Open GoM.

Table 2. GoM air-sea $\mathrm{CO}_{2}$ flux summary

\begin{tabular}{|c|c|c|c|c|}
\hline & & NGoM & Open GoM & Gulf wide \\
\hline & & & mmol m$~^{-2} d^{-1}$ & \\
\hline \multirow{6}{*}{ This work } & Spring & $4.93 \pm 10.55$ & $2.91 \pm 1.35$ & $2.48 \pm 3.75$ \\
\hline & Summer & $1.71 \pm 6.19$ & $-1.83 \pm 0.42$ & $-1.55 \pm 2.25$ \\
\hline & Fall & $4.79 \pm 4.93$ & $0.17 \pm 1.04$ & $0.45 \pm 2.47$ \\
\hline & Winter & $10.00 \pm 9.50$ & $5.80 \pm 2.24$ & $5.40 \pm 4.30$ \\
\hline & & \multicolumn{3}{|c|}{$\mathrm{mol} \mathrm{m}^{-2} \mathrm{yr}^{-1}$} \\
\hline & Annual & $1.96 \pm 2.63$ & $0.64 \pm 0.42$ & $0.62 \pm 1.06$ \\
\hline $\begin{array}{c}\text { Xue et al., } \\
2016\end{array}$ & Annual & $0.32 \pm 0.74$ & $1.04 \pm 0.46$ & $0.71 \pm 0.54$ \\
\hline $\begin{array}{l}\text { Robbins et } \\
\text { al., } 2014\end{array}$ & Annual & $0.44 \pm 0.37$ & $0.48 \pm 0.07$ & $0.19 \pm 0.08$ \\
\hline
\end{tabular}




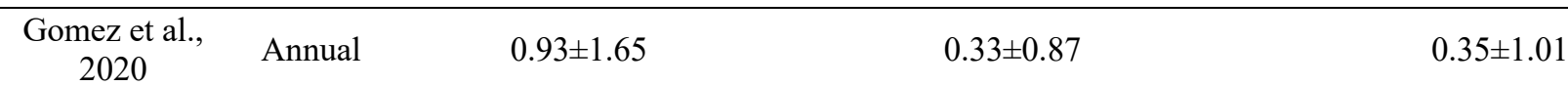

\section{Discussion}

In this study, we demonstrate that the regional high-resolution carbon model can reproduce the spatial and seasonal patterns of ocean surface $\mathrm{pCO}_{2}$ and generate reliable TA/DIC profiles on the NGoM shelf. We have detected a consistent acidification trend in the GoM over the past two decades. In this session, we further diagnose river discharge and global ocean's impacts on the GoM carbon system via a comparison between the control experiment (His) and the two perturbed experiments (Bry and NoR), followed by a discussion of model uncertainty.

\subsection{Contribution from River and Global Ocean}

435 Two sets of perturbed experiments (Bry, NoR) are performed to complement the control experiment (His). One with the clamped boundary conditions that repeat the DIC and TA level as that of the year 2000, the other with the river forcing removed to examine the impact of fluvial input on the coastal carbon system. Figure 11 shows the multiyear averaged rate of change and mean levels of the four carbon variables $\left(p C \mathrm{C}_{2}, p H, \Omega_{\mathrm{Arag}}\right.$, and $\mathrm{CO}_{2}$ flux) simulated by the three experiments. Table 3 summarizes the mean levels of $\mathrm{pCO}_{2}$ over the NGoM and Open GoM. The definition of the $\mathrm{pCO}_{2}{ }^{\text {th }}$, the $\mathrm{pCO}_{2}{ }^{\text {nt }}$, the $\mathrm{pCO}_{2}{ }^{\mathrm{GPP}}$, 440 and the $\mathrm{pCO}_{2}{ }^{\text {flux }}$ can be found in Sect. 4.1. The $\mathrm{pCO}_{2}{ }^{\text {mixing }}$ is defined in Eq. (7), which reflects the $\mathrm{pCO}_{2}$ level due to the heterogeneous water mixing. It can also be considered as the $\mathrm{pCO}_{2}$ level determined by the water with a multiyear mean temperature and without the influence from gross primary production or air-sea $\mathrm{CO}_{2}$ flux.

$$
p \mathrm{CO}_{2}{ }^{n t}=\mathrm{PCO}_{2}{ }^{\mathrm{GPP}}+\mathrm{pCO}_{2}{ }^{\text {flux }}+\mathrm{pCO}_{2}{ }^{\text {mixing }}
$$

445 The most salient difference among the three experiments is the significant elevation of annual mean $p \mathrm{CO}_{2}$ level (in Fig. 11) in the NGoM during the NoR experiment, combined with a significantly reduced carbon sink during summer (in Fig. 12, from 0.287 to $-0.093 \mathrm{Tg}$ season $^{-1}$ using His as a benchmark). The difference can be better resolved by the $\mathrm{pCO}_{2}$ decomposition results shown in Table 3, where a drastic change in water carbon system emerges in NGoM during the NoR experiment (as compared to the other experiments with river input), evidenced by the large $\mathrm{pCO}_{2}{ }^{\text {mixing }}$ value deviated from that of His and Bry experiment in the NGoM region during spring, summer, and winter. The low values of $\mathrm{pCO}_{2}{ }^{\mathrm{nt}}$ in $\mathrm{NGoM}$ during summer can be explained by a strong biological drawdown of $\mathrm{CO}_{2}$ associated with the high productivity fuelled by riverine nutrient supply. A $\mathrm{pCO}_{2}{ }^{\mathrm{GPP}}$ component of -35.35 and $-35.46 \mu \mathrm{atm}$ corresponding to the strong biological drawdown of $\mathrm{CO}_{2}$ in Bry and His experiments are in sharp contrast to that of the NoR experiment, which is only $-3.10 \mu \mathrm{atm}$. Consequently, distinct patterns of $\mathrm{CO}_{2}$ air-sea flux are shown in Fig. 12, and highly contrasting $\mathrm{CO}_{2}$ air-sea flux-induced surface $\mathrm{pCO}_{2}$ changes are shown in 455 Table $3\left(\mathrm{pCO}_{2}{ }^{\text {flux }}\right)$. The summer $\mathrm{pCO}_{2}{ }^{\text {flux }}$ component for NGoM of the two experiments with river inputs exhibits a relatively large value $(\sim 43.5 \mu \mathrm{atm})$ compared with that of the NoR experiment $(0.2 \mu \mathrm{atm})$, demonstrating much smaller disequilibrium between oceanic and atmospheric $\mathrm{pCO}_{2}$ when rivers are absent. The changes introduced by removing the river showcase the 
https://doi.org/10.5194/bg-2021-339

Preprint. Discussion started: 17 December 2021

(c) Author(s) 2021. CC BY 4.0 License.

(c) (i)

dominating impact of river input to the $\mathrm{NGoM}$ carbon system in terms of gross primary production, surface $\mathrm{pCO}_{2}$ level, and air-sea $\mathrm{CO}_{2}$ exchange.

The Bry experiment is intended to resemble a GoM carbon system evolving with local carbon forcing without the influence of secondary carbon accumulation transported from the global ocean. From Fig. 11, we can see the directions (+/- signs) of the trend of all four carbon variables are preserved for all three experiments. This means under both perturbations, the regional ocean continued to have an acidifying tendency with increasing $\mathrm{pCO}_{2}$, decreasing $\mathrm{pH}$, decreasing $\Omega_{\text {Arag, }}$, and increasing $\mathrm{CO}_{2}$ air-sea flux. This result is intuitively expected as the local atmospheric $\mathrm{pCO}_{2}$ keeps increasing at a faster rate than that of the ocean, which should determine the direction of ocean carbon system change. Results from Table 3 show a close resemblance in the magnitude and seasonal pattern between Bry and His experiment in the Open GoM region, with a small yet steady reduction in $\mathrm{pCO}_{2}{ }^{\text {mixing }}$ for the Bry experiment among all seasons. The small reductions in $\mathrm{pCO}_{2}{ }^{\text {mixing }}$ of the Bry experiment compared to that of His reflect the contribution from extraneous carbon accumulation from the global ocean that is included in the His experiment. As expected, slightly greater $\mathrm{CO}_{2}$ sink values are reported in Fig. 12 for Bry than His. Since the Bry experiment has a smaller carbon accumulation in the Open GoM region compared to that of the His experiment, the ocean surface requires a slightly greater carbon uptake to reach equilibrium with the atmosphere. The acidification trend results can be seen from Fig. 11(b), where intensified acidification trends are simulated for His experiment $\left(-0.0015789 \mathrm{yr}^{-1}\right)$ compared with that of Bry $\left(-0.0015396 \mathrm{yr}^{-1}\right)$ and NoR $\left(-0.0015243 \mathrm{yr}^{-1}\right)$. Combining the results from the three experiments, we conclude that, in addition to elevated atmospheric $\mathrm{CO}_{2}$ level, both inputs from MARS and global oceans contribute to the overall acidification trend in GoM, with the impacts from MARS mainly limited to the NGoM shelf region and global ocean's impacts spanning in the Open GoM.

Table 3. Sea surface $\mathrm{pCO}_{2}$ decomposition among experiments

\begin{tabular}{|c|c|c|c|c|c|c|c|}
\hline & \multirow{2}{*}{$\begin{array}{l}\text { unit: } \\
\text { patm }\end{array}$} & \multicolumn{3}{|c|}{ NGoM } & \multicolumn{3}{|c|}{ Open GoM } \\
\hline \multirow{6}{*}{ Spring } & & His & Bry & NoR & His & Bry & NoR \\
\hline & $p C O_{2}^{t h}$ & 315.75 & 315.29 & 316.83 & 357.09 & 356.57 & 358.31 \\
\hline & $p C O_{2}{ }^{n t}$ & 432.75 & 432.11 & 423.55 & 399.59 & 399.14 & 399.09 \\
\hline & $p C \mathrm{C}_{2}{ }^{G P P}$ & -26.83 & -26.79 & -3.34 & -2.95 & -2.96 & -2.64 \\
\hline & $p C O_{2}{ }^{\text {flux }}$ & 56.83 & 57.41 & 49.24 & 3.41 & 3.46 & 3.46 \\
\hline & $p C \mathrm{O}_{2}$ mixing & 402.75 & 401.49 & 377.65 & 399.12 & 398.64 & 398.27 \\
\hline \multirow{4}{*}{ Summer } & $p C O_{2}^{t h}$ & 429.9 & 429.28 & 431.38 & 428.65 & 428.04 & 430.13 \\
\hline & $p C O_{2}{ }^{n t}$ & 327.13 & 326.63 & 364.24 & 382.49 & 382.09 & 380.7 \\
\hline & $p C \mathrm{O}_{2}{ }^{G P P}$ & -35.46 & -35.35 & -3.1 & -3.44 & -3.36 & -2.09 \\
\hline & $p C O_{2}{ }^{\text {flux }}$ & 43.41 & 43.57 & 0.2 & -2.38 & -2.34 & -2.19 \\
\hline
\end{tabular}


https://doi.org/10.5194/bg-2021-339

Preprint. Discussion started: 17 December 2021

(c) Author(s) 2021. CC BY 4.0 License.

\begin{tabular}{|c|c|c|c|c|c|c|c|}
\hline & $p C O_{2}^{\text {mixing }}$ & 319.18 & 318.41 & 367.14 & 388.31 & 387.79 & 384.97 \\
\hline \multirow{5}{*}{ Fall } & $p \mathrm{CO}_{2}{ }^{\text {th }}$ & 374.01 & 373.47 & 375.3 & 406.92 & 406.34 & 408.32 \\
\hline & $p C O_{2}{ }^{n t}$ & 353.69 & 353.43 & 358.06 & 370.78 & 370.54 & 370.28 \\
\hline & $p C O_{2}{ }^{G P P}$ & -13.64 & -13.61 & -1.72 & -1.69 & -1.63 & -1.27 \\
\hline & $p C \mathrm{O}_{2}^{\text {flux }}$ & 63.87 & 64.08 & 58.23 & 0.19 & 0.23 & 0.25 \\
\hline & $p C \mathrm{O}_{2}^{\text {mixing }}$ & 303.47 & 302.97 & 301.56 & 372.28 & 371.94 & 371.29 \\
\hline \multirow{5}{*}{ Winter } & $p \mathrm{CO}_{2}^{\text {th }}$ & 270.51 & 270.12 & 271.44 & 340.54 & 340.06 & 341.72 \\
\hline & $p C \mathrm{O}_{2}{ }^{n t}$ & 458.11 & 457.77 & 432.23 & 393.35 & 392.79 & 393.45 \\
\hline & $p C \mathrm{O}_{2}{ }^{G P P}$ & -8.01 & -8.06 & -1.88 & -1.77 & -1.82 & -1.67 \\
\hline & $p \mathrm{CO}_{2}{ }^{\text {flux }}$ & 89.62 & 90.03 & 121.45 & 6.85 & 6.92 & 6.83 \\
\hline & $p C O_{2}^{\text {mixing }}$ & 376.5 & 375.8 & 312.65 & 388.27 & 387.7 & 388.29 \\
\hline
\end{tabular}

480

(a) $\mathrm{pCO}_{2}$

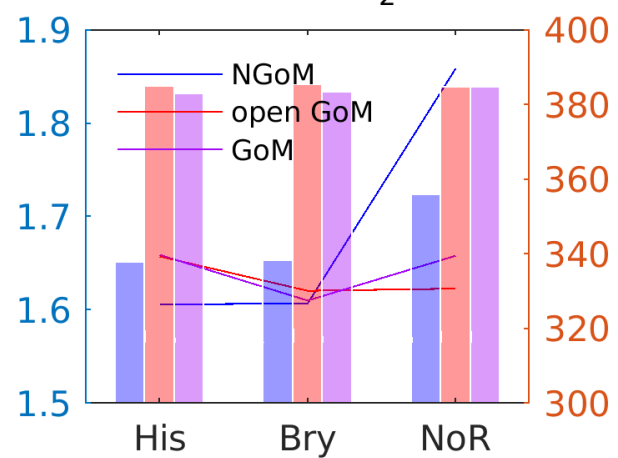

(c) $\mathrm{CO}_{2}$ Flux

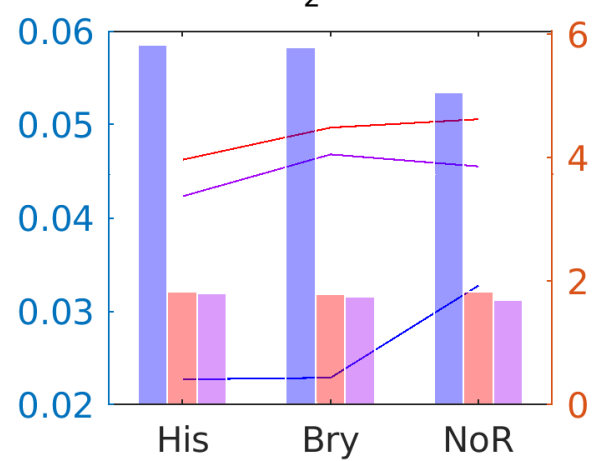

(b) $\mathrm{pH}$
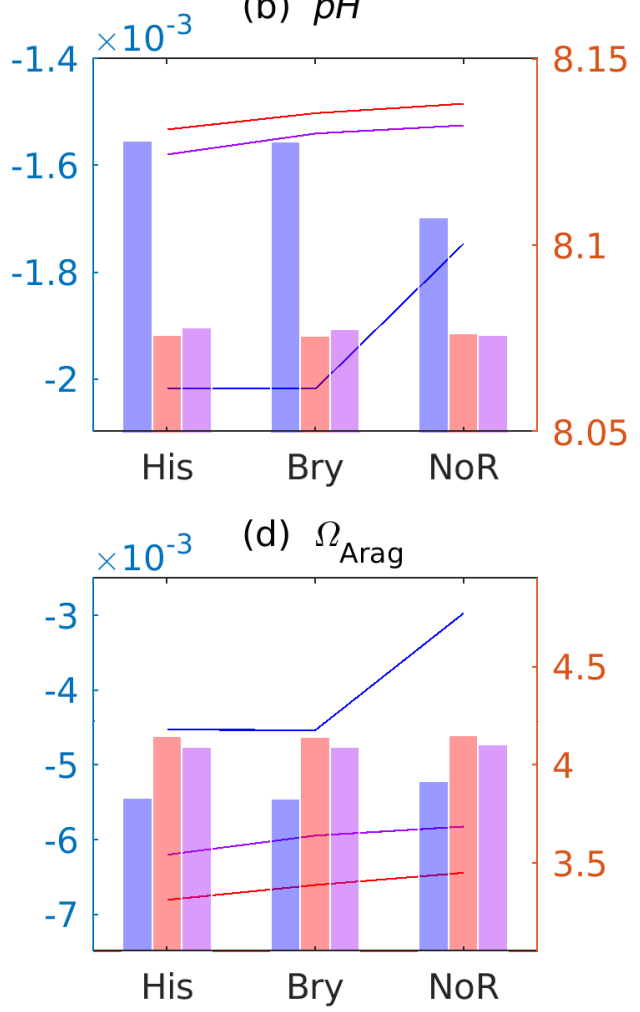

Figure 11: Multiyear synoptic of sea surface $\mathrm{pCO}_{2}, p H, \mathrm{CO}_{2}$ air-sea flux, $\Omega_{\mathrm{Arag}}$ with His, Bry, and NoR experiment. Solid lines referring to the left axis denote the annual rate of change over 2001 to 2019 , color bars referring to the right axis denote the mean level over 2001-2019. Color legend: blue - NGoM, red - Open GoM, purple - GoM wide for both the line plot and the bar plot. 
https://doi.org/10.5194/bg-2021-339

Preprint. Discussion started: 17 December 2021

(c) Author(s) 2021. CC BY 4.0 License.

A likely warmer climate combined with heavier precipitation and greater river discharge is predicted in the following years for MARS (Dai et al., 2020; Fischer \& Knutti, 2015; Frei et al., 1998; Tao et al., 2014), although climate change might reduce precipitation for some low and middle latitudes regions (Arora \& Boer, 2001; Na, Fu, \& Kodama, 2020). A warmer climate will reduce the momentum of the Loop Current, and less tropic water (reduce by about 20-25\%) will be introduced into the GoM from the Caribbean (Liu et al., 2012). As a consequence, Loop Current might penetrate less into the NGoM and reduce the upwelling along the NGoM and WF slope. Stronger river discharge with nutrient loads will exacerbate the NGoM acidification in bottom water (Laurent et al., 2018) while increasing the surface water biological $\mathrm{CO}_{2}$ utilization and removal, creating larger river plume regions that exhibit distinct carbon footprint compared to its surrounding waters. Such predictions resemble the perturbation prescribed in the Bry and NoR experiments, where reduced global ocean impact can be assessed by the difference between Bry and His experiments, and impacts from increased river discharge can be assessed by the difference between His and NoR experiments. We anticipate the Open GoM to be a stronger carbon sink in the future under the projection of Loop Current weakening. And the NGoM will continue to be a strong carbon sink with the sink region expanded in response to predicted greater river discharge and smaller momentum in Loop Current.

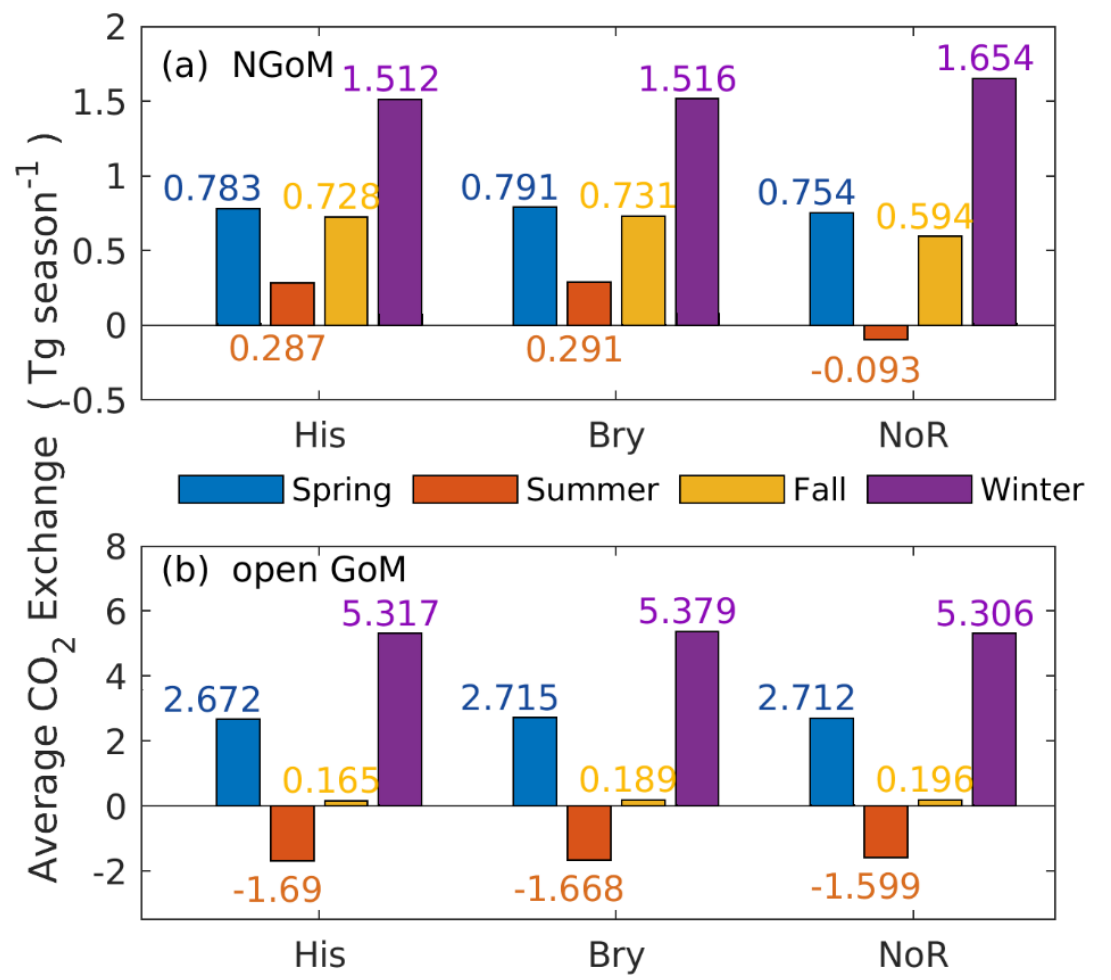

Figure 12: Seasonal air-sea $\mathrm{CO}_{2}$ exchange at NGoM and Open GoM region among the His (historical), Bry (fixed boundary), and NoR (non-river) experiment.

\subsection{Model-Data Discrepancy and Model Uncertainty}

Field samples of the carbon system give us synoptic knowledge of the carbon cycle in the ocean. However, carbon system attributes are subject to large fluctuation due to temperature, salinity, mixing, and biological activities, current observations of 
https://doi.org/10.5194/bg-2021-339

Preprint. Discussion started: 17 December 2021

(c) Author(s) 2021. CC BY 4.0 License.

\section{(c) (i)}

the carbon system at the sea surface or vertically along transects are far from enough to reveal the carbon system evolution in the GoM. As ship-based observations are limited by the spatial coverage and temporal coverage, mooring observations have a high-frequency $(\sim 3 \mathrm{~h})$ in time but only cover limited geological locations. ML model derived from remote sensing and cruise data inherit the bias from satellite ocean color products and ship-based measurements, and more importantly, it assumes the training data contains all information that defines the system it is trying to predict, which is not necessarily true. One benefit of the numerical models is to offer information to bridge fragmentary knowledge, fill in the gaps between observation and reality. However, the marine carbon cycle is admittedly a complex process. Several simplifications and parameterizations are needed to perform a numerical simulation. Nevertheless, specifications for some key processes may warrant further investigation and better parameterization: 1) The multiple alkalinity generation processes in the sediment pool in current experiments are linked linearly with the aerobic decomposition of PON with a fixed ratio, which can potentially induce large bias during high PON concentration. The anoxic zone chemistry component can be added to properly simulate the carbonate system in oxygen-deficient conditions (Raven, Keil, \& Webb, 2021), which can prevail in bottom boundary layer waters in coastal regions in NGoM, especially during summer. Adding in anoxic zone chemistry will also allow a more diversified prescription for TA generation, which plays a key role in the understanding of sediment $p H$ dynamics (Gustafsson et al. 2019; Middelburg, Soetaert \& Hagens, 2020). 2) In our model, the density-related fragmentation/flocculation of detritus OM is simplified with one particulate and one dissolved pool, each with a fixed sinking rate. Coagulation and flocculation can transform DOC into particulate OM, or subsequently form large aggregates, whose remineralization rate can be much faster (Ploug et al., 1999). The remineralization-sinking dynamic determined the fate of OM decomposition (and water column DIC profile) and should be allowed to have more degree of freedom in future model development. 3) Calcification in this work can reflect the primary factors regulating marine calcification. However, important feedback from water acidity on the calcification is omitted due to the overall supersaturation with aragonite in GoM shelf waters. Therefore, the modeled $\mathrm{CaCO}_{3} / \mathrm{PON}$ ratio could not reflect the decreasing trends of the $\mathrm{CaCO}_{3} / \mathrm{PON}$ ratio under acidification (Zondervan et al., 2001). 4) Phytoplankton groups can play different roles in carbon cycling given their different sizes, sinking rates, calcification rates, etc., and their relative ratio would be critical to the carbon dynamic (Le Moigne et al. 2015; Poulton et al. 2007). The interplay between zooplankton grazing and phytoplankton bloom in this work captured the seasonal dynamic but only had fixed modes toward nutrient levels. High nutrient concentration favors the success of diatom, and lower nutrient level gives small phytoplankton a competitive advantage in NGoM (Aké-Castillo \& Vázquez, 2008; Chakraborty \& Lohrenz, 2015; Qian et al., 2003; Strom \& Strom, 1996). More phytoplankton groups and possible predation avoidance mechanisms could be added to the model to give the bloom pattern (and subsequently the carbon export) more variance (Liszka, 2018; Rost \& Riebesell, 2004). 5) Adding the higher trophic level biology could be the next step to improve the model. Marine fishes are reported to produce precipitated carbonates within their intestines at high rates and contribute to TA increase in the top 1000 meters of ocean waters (Wilson et al., 2009). 6) This model did not include sediment silicate weathering and carbon flux through atmospheric deposition, which can potentially be important sources/sinks of carbon to the ocean waters as well (Jurado et al., 2008; Wallmann et al. 2008). 
https://doi.org/10.5194/bg-2021-339

Preprint. Discussion started: 17 December 2021

(c) Author(s) 2021. CC BY 4.0 License.

(c) (i)

\section{Conclusions}

Building upon a Global Climate \& Earth system model, the high-resolution regional carbon model can reliably simulate the spatial and temporal pattern of the surface ocean carbon system in the GoM. In this study, we show for the first time a solid validation of a regional carbon model via direct comparison against high-frequency $\mathrm{CO}_{2}$ buoys, TA/DIC vertical profiles along the coastal transects, remote sensing-based ML model product, and underway $\mathrm{pCO}_{2}$ measurements (surface). We calculated the decadal trends of important carbon system variables such as $p \mathrm{CO}_{2}, \mathrm{pH}$, air-sea $\mathrm{CO}_{2}$ exchange, and $\Omega$ over the NGoM and Open GoM regions.

The GoM surface $\mathrm{pCO}_{2}$ values experience a steady increase from 2001 to 2019 , with an increasing rate of $1.61 \mu \mathrm{atm} \mathrm{yr}^{-1}$ in $\mathrm{NGoM}$ and $1.66 \mu \mathrm{atm} \mathrm{yr}^{-1}$ in Open GoM, respectively. Correspondingly, the ocean surface $p H$ is declining at a rate of 0.0020

$550 \mathrm{yr}^{-1}$ and $0.0015 \mathrm{yr}^{-1}$ for NGoM and Open GoM, respectively. The surface $\Omega$ over the NGoM and Open GoM region remain supersaturated with aragonite during the time span of the model but with a slightly decreasing trend. The carbon sink of both NGoM and Open GoM region have increasing trends and will continue to increase at a faster pace in the coming years under the prospect of climate change and the rising atmospheric $\mathrm{pCO}_{2}$.

555 We decouple the influence on surface $\mathrm{pCO}_{2}$ into thermal, nonthermal components and further analyze the surface $p \mathrm{CO}_{2}$ changes due to gross primary production and air-sea $\mathrm{CO}_{2}$ flux. We find that the low temperature during winter and the biological uptake during spring and summer are the primary drivers making GoM an overall $\mathrm{CO}_{2}$ sink. During the modeled period of 2001-2009,

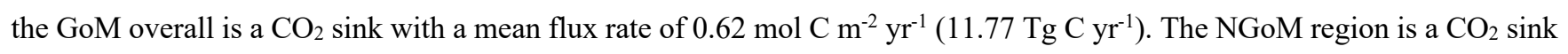
year-round and is very susceptible to changes in river forcing. The Open GoM region is dominated by thermal effects and converts from carbon sink to a source during summer.

Historical simulation (His) and perturbed tests (Bry, NoR) are performed to determine whether observed changes in the GoM carbon system are driven by secondary effects of carbon accumulation from the global ocean or local forcing such as river inputs. The results show that, in addition to the increasing atmospheric $\mathrm{pCO}_{2}$ over the GoM, the spatial distribution and trend

565 in carbon system variables could only be explained when the effects of carbon accumulation via boundary conditions and the impact from river discharge are included. With a projected warming climate, we anticipate the GoM to be a stronger carbon sink due to an elevated river discharge and reduced impact from the global ocean.

\section{Code/Data availability:}

Author contribution: Z. George Xue designed the experiments and Le Zhang carried them out. Le Zhang developed the model code and performed the simulations. Le Zhang and Z. George Xue prepared the manuscript. 
https://doi.org/10.5194/bg-2021-339

Preprint. Discussion started: 17 December 2021

(c) Author(s) 2021. CC BY 4.0 License.

Competing interests: The authors declare that they have no conflict of interest.

Acknowledgment: Research support provided through the National Science Foundation (award number OCE-1635837; EnvS 1903340; OCE- 2049047; OCE-2054935), NASA (award number NNH17ZHA002C), Louisiana Board of Regents (award number NASA/LEQSF (2018-20)-Phase3-11), NOAA Graduate Research Fellowship in Ocean, Coastal and Estuarine Acidification (OA R/CWQ-11). Computational support was provided by the High-Performance Computing Facility (clusters SuperMIC and QueenBee3) at Louisiana State University. Calculated $\mathrm{CO}_{2}$ flux data is available at the LSU mass storage system and details are on the webpage of the Coupled Ocean Modeling Group at LSU (http://coastandenvironment.lsu.edu/docs/faculty/xuelab/). Data requests can be sent to the corresponding author via this webpage.

\section{References}

Adkins, J. F., Naviaux, J. D., Subhas, A. V., Dong, S., \& Berelson, W. M. (2021). The Dissolution Rate of CaCO3 in the Ocean. Annual Review of Marine Science, 13, 57-80. https://doi.org/10.1146/annurev-marine-041720-092514

Aké-Castillo, J. A., \& Vázquez, G. (2008). Phytoplankton variation and its relation to nutrients and allochthonous organic matter in a coastal lagoon on the Gulf of Mexico. Estuarine, Coastal and Shelf Science, 78(4), 705-714.

590 Anav, A., Friedlingstein, P., Kidston, M., Bopp, L., Ciais, P., Cox, P., ... Zhu, Z. (2013). Evaluating the land and ocean components of the global carbon cycle in the CMIP5 earth system models. Journal of Climate, 26(18), 6801-6843. https://doi.org/10.1175/JCLI-D-12-00417.1

Arora, V. K., \& Boer, G. J. (2001). Effects of simulated climate change on the hydrology of major river basins. Journal of Geophysical Research: Atmospheres, 106(D4), 3335-3348. https://doi.org/10.1029/2000JD900620

595 Barbero, L., Pierrot, D., Wanninkhof, R., Baringer, M. O., Byrne, R. H., Langdon, C., ... Stauffer, B. A. (2019). Dissolved inorganic carbon, total alkalinity, nutrients, and other variables collected from CTD profile, discrete bottle, and surface underway observations using CTD, Niskin bottle, flow-through pump, and other instruments from NOAA Ship Ronald H. Brown i. NOAA National Centers for Environmental Information. Dataset. Https://Doi.Org/10.25921/Yy5k-Dw60, [Accessed 2021-05-24].

600 Booij, N., Ris, R. C., \& Holthuijsen, L. H. (1999). A third-generation wave model for coastal regions: 1. Model description and validation. Journal of Geophysical Research: Oceans, 104(C4), 7649-7666.

Boscolo-Galazzo, Flavia, K. A., Crichton, A. R., Mawbey, E. M., Wade, B. S., \& Pearson, P. N. (2021). Temperature controls carbon cycling and biological evolution in the ocean twilight zone. Science, 371(6534), 1148-1152. DOI: 10.1126/science.abb6643

605 Boyd, P. W., Claustre, H., Levy, M., Siegel, D. A., \& Weber, T. (2019). Multi-faceted particle pumps drive carbon sequestration in the ocean. Nature, 568(7752), 327-335. https://doi.org/10.1038/s41586-019-1098-2

Boyer, T. P., García, H. E., Locarnini, R. A.; Zweng, M. M., Mishonov, A. V., Reagan, J. R., Weathers, K. A., Baranova, O. K., Paver, C. R.; Seidov, D., Smolyar, I. V. (2018). World Ocean Atlas 2018. [woa18_all_o16_01.nc]. NOAA National Centers for Environmental Information. Dataset. https://www.ncei.noaa.gov/archive/accession/NCEI-WOA18. Accessed 2020-10-01.

610 Buchan, J., Hirschi, J. J.-M., Blaker, A. T., \& Sinha, B. (2014). North Atlantic SST anomalies and the cold North European weather events of winter 2009/10 and December 2010. Monthly Weather Review, 142(2), 922-932. https://doi.org/10.1175/MWR-D-13-00104.1

Buesseler, K. O., Boyd, P. W., Black, E. E., \& Siegel, D. A. (2020). Metrics that matter for assessing the ocean biological carbon pump. Proceedings of the National Academy of Sciences, 117(18), 9679-9687. 
https://doi.org/10.5194/bg-2021-339

Preprint. Discussion started: 17 December 2021

(c) Author(s) 2021. CC BY 4.0 License.

Burton, E. A., \& Walter, L. M. (1987). Relative precipitation rates of aragonite and Mg calcite from seawater: Temperature or carbonate ion control?. Geology, 15(2), 111-114. https://doi.org/10.1130/0091-7613(1987)15\%3C111:RPROAA\%3E2.0. $\mathrm{CO} ; 2$

Bushinsky, S. M., Landschützer, P., Rödenbeck, C., Gray, A. R., Baker, D., Mazloff, M. R., ... Sarmiento, J. L. (2019). Reassessing Southern Ocean Air-Sea CO2 Flux Estimates With the Addition of Biogeochemical Float Observations. Global Biogeochemical Cycles, 33(11), 1370-1388. https://doi.org/10.1029/2019GB006176

Cai, W. J., Hu, X., Huang, W. J., Murrell, M. C., Lehrter, J. C., Lohrenz, S. E., .. Gong, G. C. (2011). Acidification of subsurface coastal waters enhanced by eutrophication. Nature Geoscience, 4(11), 766-770. https://doi.org/10.1038/ngeo1297 Chassignet, E. P., Smith, L. T., Halliwell, G. R., \& Bleck, R. (2003). North Atlantic simulations with the Hybrid Coordinate Ocean Model (HYCOM): Impact of the vertical coordinate choice, reference pressure, and thermobaricity. Journal of Physical Oceanography, 33(12), 2504-2526. https://doi.org/10.1175/1520-0485(2003)033\%3C2504:NASWTH\%3E2.0.CO; 2

Chakraborty, S., \& Lohrenz, S. E. (2015). Phytoplankton community structure in the river-influenced continental margin of the northern Gulf of Mexico. Marine Ecology Progress Series, 521, 31-47. https://doi.org/10.3354/meps 11107

Chen, S., Hu, C., Barnes, B. B., Wanninkhof, R., Cai, W. J., Barbero, L., \& Pierrot, D. (2019). A machine learning approach to estimate surface ocean pCO2 from satellite measurements. Remote Sensing of Environment, 228(April), $203-226$. https://doi.org/10.1016/j.rse.2019.04.019

Chen, X., Lohrenz, S. E., \& Wiesenburg, D. A. (2000). Distribution and controlling mechanisms of primary production on the Louisiana-Texas continental shelf. Journal of Marine Systems, 25(2), 179-207. https://doi.org/10.1016/S09247963(00)00014-2

635 Coble, P. G., Robbins, L. L., Daly, K. L., Cai, W. J., Fennel, K., \& Lorenz, S. E. (2010). A preliminary carbon budget for the Gulf of Mexico. Ocean Carbon and Biogeochemistry Newsletter, 3(3), 1.

Czerny, J., Schulz, K. G., Ludwig, A., \& Riebesell, U. (2013). Technical Note : A simple method for air - sea gas exchange measurements in mesocosms and its application in carbon budgeting. Biogeosciences, 10, 1379-1390. https://doi.org/10.5194/bg-10-1379-2013

640 Dai, A., Rasmussen, R. M., Liu, C., Ikeda, K., \& Prein, A. F. (2020). A new mechanism for warm-season precipitation response to global warming based on convection-permitting simulations. Climate Dynamics, 55(1), 343-368. https://doi.org/10.1007/s00382-017-3787-6

Danabasoglu, G. (2019). NCAR CESM2-WACCM-FV2 model output prepared for CMIP6 CMIP historical , Version 2019. Earth System Grid Federation, https://doi.org/10.22033/ESGF/CMIP6.11298.

645 Davis, C. E., Blackbird, S., Wolff, G., Woodward, M., \& Mahaffey, C. (2019). Seasonal organic matter dynamics in a temperate shelf sea. Progress in Oceanography, 177, 101925. https://doi.org/10.1016/j.pocean.2018.02.021

Delgado, J. A., Sudre, J., Tanahara, S., Montes, I., Hernández-Ayón, J. M., \& Zirino, A. (2019). Effect of Caribbean Water incursion into the Gulf of Mexico derived from absolute dynamic topography, satellite data, and remotely sensed chlorophyll a. Ocean Science, 15(6), 1561-1578. https://doi.org/10.5194/os-15-1561-2019

650 DeVries, T., Le Quéré, C., Andrews, O., Berthet, S., Hauck, J., Ilyina, T., ... Séférian, R. (2019). Decadal trends in the ocean carbon sink. Proceedings of the National Academy of Sciences of the United States of America, 116(24), 11646-11651. https://doi.org/10.1073/pnas.1900371116

Dickson, A. G. (1981). An exact definition of total alkalinity and a procedure for the estimation of alkalinity and total inorganic carbon from titration data. Deep Sea Research Part A. Oceanographic Research Papers, $28(6)$, 609-623.

655 https://doi.org/10.1016/0198-0149(81)90121-7

Dickson, A. G., Sabine, C. L., \& Christian, J. R. (2007). Guide to best practices for ocean CO2 measurements. North Pacific Marine Science Organization.

Dils, B., Buchwitz, M., Reuter, M., Schneising, O., Boesch, H., Parker, R., ... \& Wunch, D. (2014). The Greenhouse Gas Climate Change Initiative (GHG-CCI): comparative validation of GHG-CCI SCIAMACHY/ENVISAT and TANSO-

660 FTS/GOSAT CO 2 and CH 4 retrieval algorithm products with measurements from the TCCON. Atmospheric Measurement Techniques, 7(6), 1723-1744. https://doi.org/10.5194/amt-7-1723-2014

Doney, S. C., Fabry, V. J., Feely, R. A., \& Kleypas, J. A. (2009). Ocean acidification: The other CO2 problem. Annual Review of Marine Science, 1, 169-192. https://doi.org/10.1146/annurev.marine.010908.163834

Dzwonkowski, B., Fournier, S., Reager, J. T., Milroy, S., Park, K., Shiller, A. M., ... Sanial., V. (2018). Tracking sea surface 665 salinity and dissolved oxygen on a river-influenced, seasonally stratified shelf, Mississippi Bight, northern Gulf of Mexico. 
https://doi.org/10.5194/bg-2021-339

Preprint. Discussion started: 17 December 2021

(c) Author(s) 2021. CC BY 4.0 License.

Continental Shelf Research, 169, 25-33. https://doi.org/10.1016/j.csr.2018.09.009

Eccles, R., Zhang, H., \& Hamilton, D. (2019). A review of the effects of climate change on riverine flooding in subtropical and tropical regions. Journal of Water and Climate Change, 10(4), 687-707. https://doi.org/10.2166/wcc.2019.175

Eyring, V., Bony, S., Meehl, G. A., Senior, C. A., Stevens, B., Stouffer, R. J., \& Taylor, K. E. (2016). Overview of the Coupled Model Intercomparison Project Phase 6 (CMIP6) experimental design and organization. Geoscientific Model Development, 9(5), 1937-1958. https://doi.org/10.5194/gmd-9-1937-2016

Farmer, J. R., Hertzberg, J. E., Cardinal, D., Fietz, S., Hendry, K., Jaccard, S. L., ... Al, E. (2021). Assessment of C, N, and $\mathrm{Si}$ isotopes as tracers of past ocean nutrient and carbon cycling. Global Biogeochemical Cycles, 35(7), e2020GB006775. https://doi.org/10.1029/2020GB006775

675 Feely, R. A., Doney, S. C., \& Cooley, S. R. (2009). Ocean acidification: Present conditions and future changes in a high-CO $\mathrm{CO}_{2}$ world. Oceanography, 22(4), 36-47. https://www.jstor.org/stable/24861022

Feely, R. A., Sabine, C. L., Lee, K., Millero, F. J., Lamb, M. F., Greeley, D., ... Wong, C. S. (2002). In situ calcium carbonate dissolution in the Pacific Ocean. Global Biogeochemical Cycles, 16(4), 91-1. https://doi.org/10.1029/2002GB001866

Fennel, W. (2008). Towards bridging biogeochemical and fish-production models. Journal of Marine Systems, 71(1-2), 171-

194.

Fennel, K., Wilkin, J., Levin, J., Moisan, J., O’Reilly, J., \& Haidvogel, D. (2006). Nitrogen cycling in the Middle Atlantic Bight: Results from a three-dimensional model and implications for the North Atlantic nitrogen budget. Global Biogeochemical Cycles, 20(3), 1-14. https://doi.org/10.1029/2005GB002456

Fennel, K., Wilkin, J., Previdi, M., \& Najjar, R. (2008). Denitrification effects on air-sea CO2 flux in the coastal ocean:

685 Simulations for the northwest North Atlantic. Geophysical Research Letters, 35(24), 1-5. https://doi.org/10.1029/2008GL036147

Fennel, K., \& Wilkin, J. (2009). Quantifying biological carbon export for the northwest North Atlantic continental shelves. Geophysical Research Letters, 36(18), 2-5. https://doi.org/10.1029/2009GL039818

Fennel, K., Hetland, R., Feng, Y., \& Dimarco, S. (2011). A coupled physical-biological model of the Northern Gulf of Mexico

690 shelf: Model description, validation and analysis of phytoplankton variability. Biogeosciences, 8(7), 1881-1899. https://doi.org/10.5194/bg-8-1881-2011

Fischer, E. M., \& Knutti, R. (2015). Anthropogenic contribution to global occurrence of heavy-precipitation and hightemperature extremes. Nature Climate Change, 5(6), 560-564. DOI: 10.1038/nclimate2617

Frei, C., Schär, C., Lüthi, D., \& Davies, H. C. (1998). Heavy precipitation processes in a warmer climate. Geophysical

695 Research Letters, 25(9), 1431-1434. https://doi.org/10.1029/98GL51099

García, H. E., K. Weathers, C. R. Paver, I. Smolyar, T. P. Boyer, R. A. Locarnini, M. M. Zweng, A. V. Mishonov, O. K. Baranova, D. Seidov, and J. R. Reagan, (2019). World Ocean Atlas 2018, Volume 3: Dissolved Oxygen, Apparent Oxygen Utilization, and Oxygen Saturation. A. Mishonov Technical Ed.; NOAA Atlas NESDIS 83, 38 pp.

Gomez, F. A., Wanninkhof, R., Barbero, L., Lee, S. K., \& Hernandez, F. J. (2020). Seasonal patterns of surface inorganic

700 carbon system variables in the Gulf of Mexico inferred from a regional high-resolution ocean biogeochemical model. Biogeosciences, 17(6), 1685-1700. https://doi.org/10.5194/bg-17-1685-2020

Gustafsson, E., Hagens, M., Sun, X., Reed, D. C., Humborg, C., Slomp, C. P., \& Gustafsson, B. G. (2019). Sedimentary alkalinity generation and long-term alkalinity development in the Baltic Sea. Biogeosciences, 16(2), 437-456. https://doi.org/10.5194/bg-16-437-2019

705 Haidvogel, D. B., Arango, H., Budgell, W. P., Cornuelle, B. D., Curchitser, E., Di Lorenzo, E., ... Wilkin, J. (2008). Ocean forecasting in terrain-following coordinates: Formulation and skill assessment of the Regional Ocean Modeling System. Journal of Computational Physics, 227(7), 3595-3624. https://doi.org/10.1016/j.jcp.2007.06.016

Ho, D. T., Law, C. S., Smith, M. J., Schlosser, P., Harvey, M., \& Hill, P. (2006). Measurements of air-sea gas exchange at high wind speeds in the Southern Ocean: Implications for global parameterizations. Geophysical Research Letters, 33(16).

710 https://doi.org/10.1029/2006GL026817

Hofmann, E. E., Cahill, B., Fennel, K., Friedrichs, M. A. M., Hyde, K., Lee, C., ... Xue, J. (2011). Modeling the dynamics of continental shelf carbon. Annual Review of Marine Science, 3, 93-122. https://doi.org/10.1146/annurev-marine-120709142740

Holligan, P. M., \& Robertson, J. E. (1996). Significance of ocean carbonate budgets for the global carbon cycle. Global Change 
https://doi.org/10.5194/bg-2021-339

Preprint. Discussion started: 17 December 2021

(c) Author(s) 2021. CC BY 4.0 License.

Hu, X., \& Cai, W. J. (2011). An assessment of ocean margin anaerobic processes on oceanic alkalinity budget. Global Biogeochemical Cycles, 25(3). https://doi.org/10.1029/2010GB003859

Huang, W. J., Cai, W. J., Wang, Y., Lohrenz, S. E., \& Murrell, M. C. (2015). The carbon dioxide system on the Mississippi River-dominated continental shelf in the northern Gulf of Mexico. Journal of Geophysical Research: Oceans, 120(3), 1429-

720 1445. https://doi.org/10.1002/2014JC010498

Inskeep, W. P., \& Bloom, P. R. (1985). An evaluation of rate equations for calcite precipitation kinetics at pCO2 less than 0.01 atm and $\mathrm{pH}$ greater than 8. Geochimica et Cosmochimica Acta, 49(10), 2165-2180. https://doi.org/10.1016/00167037(85)90074-2

Irigoien, X., Flynn, K. J., \& Harris, R. P. (2005). Phytoplankton blooms: a 'loophole' in microzooplankton grazing impact?

Journal of Plankton Research, 27(4), 313-321. https://doi.org/10.1093/plankt/fbi011

Jiang, Z. P., Cai, W. J., Chen, B., Wang, K., Han, C., Roberts, B. J., ... Li, Q. (2019). Physical and Biogeochemical Controls on pH Dynamics in the Northern Gulf of Mexico During Summer Hypoxia. Journal of Geophysical Research: Oceans, 124(8), 5979-5998. https://doi.org/10.1029/2019JC015140

Jones, C. D., Arora, V., Friedlingstein, P., Bopp, L., Brovkin, V., Dunne, J., ... Zaehle, S. (2016). C4MIP-The Coupled

730 Climate-Carbon Cycle Model Intercomparison Project: Experimental protocol for CMIP6. Geoscientific Model Development, 9(8), 2853-2880. https://doi.org/10.5194/gmd-9-2853-2016

Jurado, E., Dachs, J., Duarte, C. M., \& Simo, R. (2008). Atmospheric deposition of organic and black carbon to the global oceans. Atmospheric Environment, 42(34), 7931-7939. https://doi.org/10.1016/j.atmosenv.2008.07.029

King, A. L., Jenkins, B. D., Wallace, J. R., Liu, Y., Wikfors, G. H., Milke, L. M., \& Meseck, S. L. (2015). Effects of CO2 on

735 growth rate, C: N: P, and fatty acid composition of seven marine phytoplankton species. Marine Ecology Progress Series, 537 , 59-69. https://doi.org/10.3354/meps 11458

Kishi, Michio J., Kashiwai, M., Ware, D. M., Megrey, B. A., Eslinger, D. L., Werner, F. E., ... Zvalinsky, V. I. (2007). NEMURO-a lower trophic level model for the North Pacific marine ecosystem. Ecological Modelling, 202(1-2), 12-25. https://doi.org/10.1016/j.ecolmodel.2006.08.021

740 Kishi, M. J., Ito, S. I., Megrey, B. A., Rose, K. A., \& Werner, F. E. (2011). A review of the NEMURO and NEMURO. FISH models and their application to marine ecosystem investigations. Journal of Oceanography, 67(1), 3-16. DOI: 10.1007/s10872-011-0009-4

Laurent, A., Fennel, K., Cai, W. J., Huang, W. J., Barbero, L., \& Wanninkhof, R. (2017). Eutrophication-induced acidification of coastal waters in the northern Gulf of Mexico: Insights into origin and processes from a coupled physical-biogeochemical

745 model. Geophysical Research Letters, 44(2), 946-956. https://doi.org/10.1002/2016GL071881

Laurent, A., Fennel, K., Ko, D. S., \& Lehrter, J. (2018). Climate change projected to exacerbate impacts of coastal eutrophication in the northern Gulf of Mexico. Journal of Geophysical Research: Oceans, 123(5), 3408-3426. https://doi.org/10.1002/2017JC013583

Laurent, A., Fennel, K., \& Kuhn, A. (2021). An observation-based evaluation and ranking of historical Earth system model

750 simulations in the northwest North Atlantic Ocean. Biogeosciences, 18(5), 1803-1822. https://doi.org/10.5194/bg-18-18032021

Lauvset, S. K., Carter, B. R., Perez, F. F., Jiang, L. Q., Feely, R. A., Velo, A., \& Olsen, A. (2020). Processes Driving Global Interior Ocean pH Distribution. Global Biogeochemical Cycles, 34(1), 1-17. https://doi.org/10.1029/2019GB006229

Le Moigne, F. A., Poulton, A. J., Henson, S. A., Daniels, C. J., Fragoso, G. M., Mitchell, E., ... \& Zubkov, M. (2015).

755 Carbon export efficiency and phytoplankton community composition in the A tlantic sector of the A rctic O cean. Journal of Geophysical Research: Oceans, 120(6), 3896-3912. https://doi.org/10.1002/2015JC010700

Le Quéré, C., Andrew, R. M., Friedlingstein, P., Sitch, S., Pongratz, J., Manning, A. C., ... Zhu, D. (2018). Global Carbon

Budget 2018. Earth System Science Data Discussions, 10(4), 2141-2194. https://doi.org/10.5194/essd-10-2141-2018

Lewis, E. R., \& Wallace, D. W. R. (1998). Program developed for CO2 system calculations (No. cdiac: CDIAC-105).

760 Environmental System Science Data Infrastructure for a Virtual Ecosystem. doi:10.15485/1464255.Liao, H., Yu, Y. yong, Wang, C., Han, X., \& Song, Z. (2020). An explanation for the simulated aborted ENSO events in climate models. Earth and Space Science Open Archive. https://doi.org/10.1002/essoar.10502531.1

Lindsay, K., Bonan, G. B., Doney, S. C., Hoffman, F. M., Lawrence, D. M., Long, M. C., ... Thornton, P. E. (2014). Preindustrial-control and twentieth-century carbon cycle experiments with the Earth system model CESM1(BGC). Journal of 
https://doi.org/10.5194/bg-2021-339

Preprint. Discussion started: 17 December 2021

(c) Author(s) 2021. CC BY 4.0 License.

Liu, Y., Lee, S. K., Muhling, B. A., Lamkin, J. T., \& Enfield, D. B. (2012). Significant reduction of the Loop Current in the 21st century and its impact on the Gulf of Mexico. Journal of Geophysical Research: Oceans, 117(C5). https://doi.org/10.1029/2011JC007555

Liu, Y., Lee, S. K., Enfield, D. B., Muhling, B. A., Lamkin, J. T., Muller-Karger, F. E., \& Roffer, M. A. (2015). Potential impact of climate change on the Intra-Americas Sea: Part-1. A dynamic downscaling of the CMIP5 model projections. Journal of Marine Systems, 148, 56-69. https://doi.org/10.1016/j.jmarsys.2015.01.007

Liszka, C. (2018). Zooplankton-mediated carbon flux in the Southern Ocean: influence of community structure, metabolism and behaviour (Doctoral dissertation, University of East Anglia).

Lohrenz, S. E., Cai, W. J., Chakraborty, S., Huang, W. J., Guo, X., He, R., ... Tian, H. (2018a). Satellite estimation of coastal pCO2 and air-sea flux of carbon dioxide in the northern Gulf of Mexico. Remote Sensing of Environment, 207, 71-83. https://doi.org/10.1016/j.rse.2017.12.039

Mackenzie, F. T., Lerman, A., \& Andersson, A. J. (2004). Past and present of sediment and carbon biogeochemical cycling model. Biogeosciences, 1(1), 11-32. https://doi.org/10.5194/bg-1-11-2004

Maher, D. T., \& Eyre, B. D. (2012). Carbon budgets for three autotrophic Australian estuaries: Implications for global estimates of the coastal air-water CO 2 flux. Global Biogeochemical Cycles, 26(1). https://doi.org/10.1029/2011GB004075

Mari, X., Passow, U., Migon, C., Burd, A. B., \& Legendre, L. (2017). Transparent exopolymer particles: Effects on carbon cycling in the ocean. Progress in Oceanography, 151(13-37). https://doi.org/10.1016/j.pocean.2016.11.002

Middelburg, J. J., Soetaert, K., \& Hagens, M. (2020). Ocean alkalinity, buffering and biogeochemical processes. Reviews of Geophysics, 58(3), e2019RG000681. https://doi.org/10.1029/2019RG000681

785 Millero, F. J. (1982). The effect of pressure on the solubility of minerals in water and seawater. Geochimica et Cosmochimica Acta, 46(1), 11-22. https://doi.org/10.1016/0016-7037(82)90286-1

Millero, F. J. (1995). Thermodynamics of the carbon dioxide system in the oceans. Geochimica et Cosmochimica Acta, 59(4), 661-677. https://doi.org/10.1016/0016-7037(94)00354-O

Millero, F. J. (2007). The marine inorganic carbon cycle. Chemical Reviews, 107(2), 308-341.

https://doi.org/10.1021/cr0503557

Millero, F. J. (2010). Carbonate constants for estuarine waters. Marine and Freshwater Research, 61(2), 139-142.

Milliman, J. D., Troy, P. J., Balch, W. M., Adams, A. K., Li, Y. H., \& Mackenzie, F. T. (1999). Biologically mediated dissolution of calcium carbonate above the chemical lysocline? Deep Sea Research Part I: Oceanographic Research Papers, 46(10), 1653-1669. https://doi.org/10.1016/S0967-0637(99)00034-5

795 Moore, J. K., Doney, S. C., \& Lindsay, K. (2004). Upper ocean ecosystem dynamics and iron cycling in a global threedimensional model. Global Biogeochemical Cycles, 18(4). https://doi.org/10.1029/2004GB002220

Mucci, A. (1983). The Solubility of Calcite and Aragonite in Seawater at Various Salinities, Temperatures and One Atmosphere Total Pressure. American Journal of Science, Vol. 283, pp. 780-799. https://doi.org/10.2475/ajs.283.7.780

$\mathrm{Na}, \mathrm{Y}$., Fu, Q., \& Kodama, C. (2020). Precipitation probability and its future changes from a global cloud-resolving model

800 and CMIP6 simulations. Journal of Geophysical Research: Atmospheres, 125(5), e2019JD031926. https://doi.org/10.1029/2019JD031926

Najjar, R. G., Herrmann, M., Alexander, R., Boyer, E. W., Burdige, D. J., Butman, D., ... Zimmerman, R. C. (2018). Carbon Budget of Tidal Wetlands, Estuaries, and Shelf Waters of Eastern North America. Global Biogeochemical Cycles, 32(3), 389416. https://doi.org/10.1002/2017GB005790

805 Ollila, A. (2020). Analysis of the Simulation Results of Three Carbon Dioxide (CO2) Cycle Models. Physical Science International Journal, 23(4), 1-19. https://doi.org/10.9734/psij/2019/v23i430168

Orr, J., Najjar, R., Sabine, C. L., \& Joos, F. (1999). Abiotic-howto. Internal OCMIP Report, LSCE/CEA S.

Orr, J., Najjar, R. G., Aumont, O., Bopp, L., Bullister, J. L., Danabasoglu, G., ... Yool, A. (2017). Biogeochemical protocols and diagnostics for the CMIP6 Ocean Model Intercomparison Project (OMIP). Geoscientific Model Development, 10(6), 2169-

810 2199. https://doi.org/10.5194/gmd-10-2169-2017

Ploug, H., Grossart, H. P., Azam, F., \& Jørgensen, B. B. (1999). Photosynthesis, respiration, and carbon turnover in sinking marine snow from surface waters of Southern California Bight: implications for the carbon cycle in the ocean. Marine Ecology Progress Series, 179, 1-11. doi:10.3354/meps179001

Poulton, A. J., Adey, T. R., Balch, W. M., \& Holligan, P. M. (2007). Relating coccolithophore calcification rates to 815 phytoplankton community dynamics: Regional differences and implications for carbon export. Deep Sea Research Part II: 
https://doi.org/10.5194/bg-2021-339

Preprint. Discussion started: 17 December 2021

(c) Author(s) 2021. CC BY 4.0 License.

Topical Studies in Oceanography, 54(5-7), 538-557. https://doi.org/10.1016/j.dsr2.2006.12.003

Qian, Y., Jochens, A. E., Kennicutt Ii, M. C., \& Biggs, D. C. (2003). Spatial and temporal variability of phytoplankton biomass and community structure over the continental margin of the northeast Gulf of Mexico based on pigment analysis. Continental Shelf Research, 23(1), 1-17. https://doi.org/10.1016/S0278-4343(02)00173-5

820 Raven, J. A., \& Giordano, M. (2009). Biomineralization by photosynthetic organisms: Evidence of coevolution of the organisms and their environment? Geobiology, 7(2), 140-154. https://doi.org/10.1111/j.1472-4669.2008.00181.x

Raven, M. R., Keil, R. G., \& Webb, S. M. (2021). Microbial sulfate reduction and organic sulfur formation in sinking marine particles. Science, 371(6525), 178-181. DOI: 10.1126/science.abc6035

Regnier, P., Friedlingstein, P., Ciais, P., Mackenzie, F. T., Gruber, N., Janssens, I. A., ... Thullner, M. (2013). Anthropogenic perturbation of the carbon fluxes from land to ocean. Nature Geoscience, 6(8), 597-607. https://doi.org/10.1038/ngeo1830 Reiman, J. H., \& Xu, Y. J. (2019). Dissolved carbon export and CO2 outgassing from the lower Mississippi River Implications of future river carbon fluxes. Journal of Hydrology, 578(July), 124093. https://doi.org/10.1016/j.jhydrol.2019.124093

Renforth, P., \& Henderson, G. (2017). Assessing ocean alkalinity for carbon sequestration. Reviews of Geophysics, 55(3), 636-674. https://doi.org/10.1002/2016RG000533

Riebesell, U., Zondervan, I., Rost, B., Tortell, P. D., Zeebe, R. E., \& Morel, F. M. (2000). Reduced calcification of marine plankton in response to increased atmospheric CO2. Nature, 407(6802), 364-367.

Robbins, L. L., Daly, K. L., Barbero, L., Wanninkhof, R., He, R., Zong, H., ... Smith, C. G. (2018). Spatial and Temporal Variability of pCO2, Carbon Fluxes, and Saturation State on the West Florida Shelf. Journal of Geophysical Research: Oceans,

835 123(9), 6174-6188. https://doi.org/10.1029/2018JC014195

Robbins, L. L., Wanninkhof, R., Barbero, L., Hu, X., Mitra, S., Yvon-Lewis, S., ... and Ryerson, T. (2014). Air-Sea Exchange, Report of The U.S. Gulf of Mexico Carbon Cycle Synthesis Workshop. Ocean Carbon and Biogeochemistry Program and North American Carbon Program, 66.

Robertson, R., \& Hartlipp, P. (2017). Surface wind mixing in the regional ocean modeling system (ROMS). Geoscience

840 Letters, 4(1), 1-11. DOI 10.1186/s40562-017-0090-7

Rost, B., \& Riebesell, U. (2004). Coccolithophores and the biological pump: responses to environmental changes. Coccolithophores, Springer, 99-125. DOI: 10.1007/978-3-662-06278-4_5

Saha, S., et al. (2010), NCEP Climate Forecast System Reanalysis (CFSR) Selected Hourly Time-Series Products, January 1979 to December 2010, https://doi.org/10.5065/D6513W89, Research Data Archive at the National Center for Atmospheric

845 Research, Computational and Information Systems Laboratory, Boulder, Colo. Accessed 22 Oct 2020.

Saha, S., et al. (2011), NCEP Climate Forecast System Version 2 (CFSv2) 6-hourly Products, https://doi.org/10.5065/D61C1TXF, Research Data Archive at the National Center for Atmospheric Research, Computational and Information Systems Laboratory, Boulder, Colo. (Updated daily.) Accessed 22 Oct 2020.

Shchepetkin, A. F., \& McWilliams, J. C. (2005). The regional oceanic modeling system (ROMS): A split-explicit, free-surface,

850 topography-following-coordinate oceanic model. Ocean Modelling, 9(4), 347-404. https://doi.org/10.1016/j.ocemod.2004.08.002

Shen, Y., Fichot, C. G., \& Benner, R. (2012). Floodplain influence on dissolved organic matter composition and export from the Mississippi-Atchafalaya River system to the Gulf of Mexico. Limnology and Oceanography, 57(4), 1149-116. https://doi.org/10.4319/lo.2012.57.4.1149

855 Skamarock, W. C., Klemp, J. B., Dudhi, J., Gill, D. O., Barker, D. M., Duda, M. G., .. Powers, J. G. (2005). A Description of the Advanced Research WRF Version 3. Technical Report, (June), 113. https://doi.org/10.5065/D6DZ069T

Smith, S. V., \& Hollibaugh, J. T. (1993). Coastal metabolism and the oceanic organic carbon balance. Reviews of Geophysics, 31(1), 75-89. https://doi.org/10.1029/92RG02584

Stackpoole, S. M., Stets, E. G., Clow, D. W., Burns, D. A., Aiken, G. R., Aulenbach, B. T., ... Striegl, R. G. (2017). Spatial

860 and temporal patterns of dissolved organic matter quantity and quality in the Mississippi River Basin, $1997-2013$. Hydrological Processes, 31(4), 902-915. https://doi.org/10.1002/hyp.11072

Strom, S. L., \& Strom, M. W. (1996). Microplankton growth, grazing, and community structure in the northern Gulf of Mexico. Marine Ecology Progress Series, 130, 229-240. doi:10.3354/meps130229

Sunda, W. G., \& Cai, W. J. (2012). Eutrophication induced CO2-acidification of subsurface coastal waters: Interactive effects 865 of temperature, salinity, and atmospheric P CO2. Environmental Science and Technology, 46(19), 10651-10659. 
https://doi.org/10.5194/bg-2021-339

Preprint. Discussion started: 17 December 2021

(c) Author(s) 2021. CC BY 4.0 License.

https://doi.org/10.1021/es300626f

Tao, B., Tian, H., Ren, W., Yang, J., Yang, Q., He, R., ... Lohrenz, S. (2014). Increasing Mississippi river discharge throughout the 21 st century influenced by changes in climate, land use, and atmospheric CO2. Geophysical Research Letter, 41(14), 49784986. https://doi.org/10.1002/2014GL060361.Received

870 Todd-Brown, K. E. O., Randerson, J. T., Hopkins, F., Arora, V., Hajima, T., Jones, C., ... Allison, S. D. (2014). Changes in soil organic carbon storage predicted by Earth system models during the 21st century. Biogeosciences, 11(8), 2341-2356. https://doi.org/10.5194/bg-11-2341-2014

Torres, R., Pantoja, S., Harada, N., González, H. E., Daneri, G., Frangopulos, M., ... Fukasawa, M. (2011). Air-sea CO2 fluxes along the coast of Chile: From CO2 outgassing in central northern upwelling waters to CO2 uptake in southern Patagonian fjords. Journal of Geophysical Research: Oceans, 116(9), 1-17. https://doi.org/10.1029/2010JC006344

Turner, J. T. (2015). Zooplankton fecal pellets, marine snow, phytodetritus and the ocean's biological pump. Progress in Oceanography, 130, 205-248. https://doi.org/10.1016/j.pocean.2014.08.005

Wallmann, K., Aloisi, G., Haeckel, M., Tishchenko, P., Pavlova, G., Greinert, J., ... \& Eisenhauer, A. (2008). Silicate weathering in anoxic marine sediments. Geochimica et Cosmochimica Acta, 72(12), 2895-2918. https://doi.org/10.1016/j.gca.2008.03.026

Wang, H., Hu, X., Cai, W. J., \& Rabalais, N. N. (2016). Comparison of fCO 2 trends in river dominant and ocean dominant ocean margins. American Geophysical Union, AH24A-0039.

Wang, X., Cai, Y., Guo, L., \& Dist, V. in abundance and size. (2013). Variations in abundance and size distribution of carbohydrates in the lower Mississippi River, Pearl River and Bay of St Louis. Estuarine, Coastal and Shelf Science, 126, 61-

885 69. https://doi.org/10.1016/j.ecss.2013.04.008

Wanninkhof, R. (1992). Relationship between wind speed and gas exchange over the ocean. Journal of Geophysical Research: Oceans, 97(C5), 7373-7382. https://doi.org/10.1029/92JC00188

Wanninkhof, R. (2014). Relationship between wind speed and gas exchange over the ocean revisited. Limnology and Oceanography: Methods, 12(JUN), 351-362. https://doi.org/10.4319/lom.2014.12.351

890 Wanninkhof, R., Zhang, J.-Z., Baringer, M. O., Langdon, C., Cai, W.-J., Salisbury, J. E., \& Byrne, R. H. (2013). Partial pressure (or fugacity) of carbon dioxide, dissolved inorganic carbon, alkalinity, temperature, salinity and other variables collected from Surface underway, discrete sample and profile observations using Alkalinity titrator, Barometric pressure se. NOAA National Centers for Environmental Information. Https://Doi.Org/10.3334/Cdiac/Otg.Clivar_nacp_east_coast_cruise_2007., [Accessed 2021-05-24].

895 Wanninkhof, R., Zhang, J.-Z., Baringer, M. O., Langdon, C., Cai, W.-J., Salisbury, J. E., \& Byrne, R. H. (2016). Partial pressure (or fugacity) of carbon dioxide, dissolved inorganic carbon, $\mathrm{pH}$, alkalinity, temperature, salinity and other variables collected from discrete sample and profile observations using CTD, bottle and other instruments from NOAA Ship RONALD H. NOAA National Centers for Environmental Information. Dataset. Https://Doi.Org/10.3334/Cdiac/Otg.Coastal_gomecc2., [Accessed 2021-05-24].

900 Wang, X., Cai, Y., \& Guo, L. (2013). Variations in abundance and size distribution of carbohydrates in the lower Mississippi River, Pearl River and Bay of St Louis. Estuarine, Coastal and Shelf Science, 126, 61-69. https://doi.org/10.1016/j.ecss.2013.04.008

Wanninkhof, R., Triñanes, J., Park, G. H., Gledhill, D., \& Olsen, A. (2019). Large Decadal Changes in Air-Sea CO2 Fluxes in the Caribbean Sea. Journal of Geophysical Research: Oceans, 124(10), 6960-6982. https://doi.org/10.1029/2019JC015366

905 Warner, J. C., Armstrong, B., He, R., \& Zambon, J. B. (2010). Development of a Coupled Ocean-Atmosphere-Wave-Sediment Transport (COAWST) Modeling System. Ocean Modelling, 35(3), 230-244. https://doi.org/10.1016/j.ocemod.2010.07.010 Wilson, R. W., Millero, F. J., Taylor, J. R., Walsh, P. J., Christensen, V., Jennings, S., \& Grosell, M. (2009). Contribution of fish to the marine inorganic carbon cycle. Science, 323(5912), 359-362. DOI: 10.1126/science.1157972

Wollast, R., \& Mackenzie, F. T. (1989). Global biogeochemical cycles and climate. Climate and Geo-Sciences, Springer, 453-

910 473. DOI: $10.1007 / 978-94-009-2446-8 \quad 26$

$\mathrm{Xu}$, Y. J., \& DelDuco, E. M. (2017). Unravelling the relative contribution of dissolved carbon by the Red River to the Atchafalaya River. Water, 9(11), 871. https://doi.org/10.3390/w9110871

Xue, Z., He, R., Fennel, K., Cai, W.-J., Lohrenz, S., Huang, W.-J., ... Zang, Z. (2016). Modeling pCO 2 variability in the Gulf of Mexico. Biogeosciences, 13(15), 4359-4377. https://doi.org/10.5194/bg-13-4359-2016

915 Yao, H., \& Hu, X. (2017). Responses of carbonate system and CO2 flux to extended drought and intense flooding in a semiarid 
https://doi.org/10.5194/bg-2021-339

Preprint. Discussion started: 17 December 2021

(c) Author(s) 2021. CC BY 4.0 License.

(c) (1)

subtropical estuary. Limnology and Oceanography, 62, S112-S130. https://doi.org/10.1002/lno.10646

Zang, Z., Xue, Z. G., Xu, K., Bentley, S. J., Chen, Q., D’Sa, E. J., \& Ge, Q. (2019). A Two Decadal (1993-2012) Numerical Assessment of Sediment Dynamics in the Northern Gulf of Mexico. Water, 11(5), 938. https://doi.org/10.3390/w11050938

Zang, Z., Xue, Z. G., Xu, K., Bentley, S. J., Chen, Q., D’Sa, E. J., Zhang, L., Ou, Y. (2020). The role of sediment-induced

920 light attenuation on primary production during Hurricane Gustav (2008). Biogeosciences, 17(20), $5043-5055$. https://doi.org/10.5194/bg-17-5043-2020

Zeebe, R., \& Wolf-Gladrow, D. (2001). CO2 in Seawater: Equilibrium, Kinetics, Isotopes. Elsevier, Amsterdam, 1-83.

Zhong, S., \& Mucci, A. (1989). Calcite and aragonite precipitation from seawater solutions of various salinities: Precipitation rates and overgrowth compositions. Chemical geology, 78(3-4), 283-299. https://doi.org/10.1016/0009-2541(89)90064-8

925 Zondervan, I., Zeebe, R. E., Rost, B., \& Riebesell, U. (2001). Decreasing marine biogenic calcification: A negative feedback on rising atmospheric pCO2. Global Biogeochemical Cycles, 15(2), 507-516. https://doi.org/10.1029/2000GB001321

Zuddas, P., \& Mucci, A. (1998). Kinetics of calcite precipitation from seawater: II. The influence of the ionic strength. Geochimica et Cosmochimica Acta, 62(5), 757-766. https://doi.org/10.1016/S0016-7037(98)00026-X 